\title{
Shallow-Water Sea Anemones (Cnidaria: Anthozoa: Actiniaria) and Tube Anemones (Cnidaria: Anthozoa: Ceriantharia) of the Galápagos Islands ${ }^{1,2}$
}

\author{
Daphne Gail Fautin, ${ }^{3,4}$ Cleveland P. Hickman 7r., ${ }^{5}$ Marymegan Daly, ${ }^{6}$ and Tina Molodtsova ${ }^{7}$
}

\begin{abstract}
We provide the first inventory of members of orders Actiniaria (sea anemones sensu stricto) and Ceriantharia (tube anemones) from the Galápagos Islands. Based on observations and collections at 48 localities throughout the archipelago that span nearly a decade, we report on eight species of actiniarians (representing families Actiniidae, Actinostolidae, Aiptasiidae, Hormathiidae, and Isophelliidae) and two of cerianthids (in families Arachnactidae and Botrucnidiferidae). We include live photographs and diagnostic features of the animals, as well as a key and map of their occurrence in the Galápagos. Two actiniarians and one cerianthid are resolved only to genus level; of those identified to species, three of the actiniarians and one of the cerianthids have an eastern Pacific distribution, one actiniarian appears to be endemic to the Galápagos Islands, and two actiniarians are broadly distributed in the Indo-West Pacific.
\end{abstract}

The NONCORAL HEXACORALLIAN cnidarians of the Galápagos Islands are poorly known. The single chapter on coelenterates in the bibliographic compendium of James (1991) concerns corals; anemones are not even mentioned in the general and summary chapters.

${ }^{1}$ D.G.F. and M.D. gratefully acknowledge grants DEB99-78106 (PEET) and DEB04-15277, respectively, from the U.S. National Science Foundation. Manuscript accepted 26 October 2006.

${ }^{2}$ Dedicated to the memory of Joel W. Hedgpeth (1911-2006), whose notes made and photos taken on travels to the Galápagos Islands in the 1960s contributed to this article.

${ }^{3}$ Corresponding author (e-mail: fautin@ku.edu).

${ }^{4}$ Department of Ecology and Evolutionary Biology, and University of Kansas Natural History Museum and Biodiversity Research Center, University of Kansas, Lawrence, Kansas 66045.

${ }^{5}$ Department of Biology, Washington and Lee University, Lexington, Virginia 24450-0303 (e-mail: hickman.c@rockbridge.net).

${ }^{6}$ Department of Evolution, Ecology, and Organismal Biology, The Ohio State University, Columbus, Ohio 43210 (e-mail: daly.66@osu.edu).

${ }^{7}$ P. P. Shirshov Institute of Oceanology of the Russian Academy of Sciences, 36 Nakhimovsky Prospect, Moscow 117997, Russian Federation (e-mail: tina@ ocean.ru).

Pacific Science (2007), vol. 61, no. 4:549-573

(C) 2007 by University of Hawai'i Press

All rights reserved
No publications of the Allan Hancock Expeditions treat anemones.

McMurrich (1893) recorded one species of littoral actiniarian, referred to as Antboloba reticulata (Dana), collected in the Galápagos on an expedition of the U.S. Fish Commission steamer Albatross; we infer that it was actually Bunodosoma grandis (see later in this section). He also described a new species, Stephanactis byalonematis, and documented another species, Actinostola callosa, from deep water in the vicinity of the Galápagos. The new species, the valid name of which is Stephanauge byalonematis (McMurrich, 1893), was collected from station 2807 (4 April 1888; $0.40^{\circ} \mathrm{N}$, $88.90^{\circ} \mathrm{W} ; 812$ fathoms $\left.[1,485 \mathrm{~m}]\right)$, and the other, the valid name of which is Actinostola crassicornis (Hertwig, 1882), was from stations 2807 and 2818 (15 April 1888; 0.48 $\mathrm{N}$, $88.10^{\circ} \mathrm{W} ; 392$ fathoms $[717 \mathrm{~m}]$ ) (Fautin 2006). There appear to be only three firstperson reports of anemones in these islands: Darwin noted two species from his 1836 visit to the archipelago (Keynes 2000) but these were not identified, and we have been able to infer the identity of only one of them; Mariscal (1966) recorded one unnamed species of Bunodactis; Okey et al. (2003, 2004) documented "anemone barrens" on Fernandina.

No adult cerianthids have been documented from the archipelago. Senna (1907) 


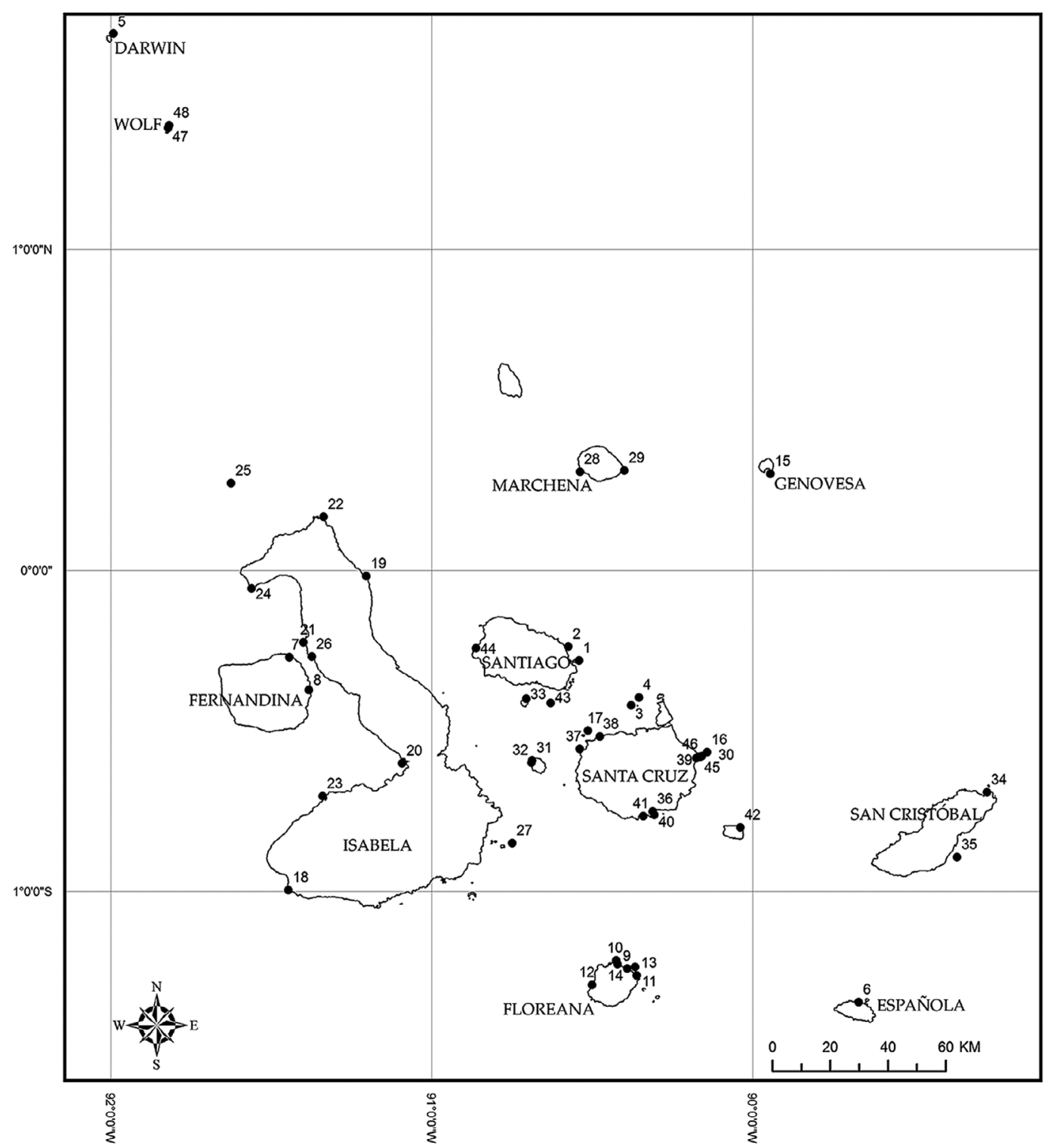

FigURE 1. Map showing distribution of sea anemones from 48 Galápagos Islands sites recorded in this publication (see Table 1).

described the pelagic cerianthid larva Dactylactis mammillata from the northern Galápagos (Liguria station 14: $3^{\circ} 15^{\prime} \mathrm{N}, 89^{\circ} 52^{\prime} 30^{\prime \prime}$ W; 0-600 m); Carlgren (1924) transferred this species to the newly established genus Syndactylactis.
We document eight species of sea anemones (order Actiniaria) and two of tube anemones (order Ceriantharia) at 48 localities in the Galápagos Archipelago (Figure 1; see Table 1) from the intertidal zone to $35 \mathrm{~m}$. All eight species of Galápagos anemones, 
TABLE 1

Localities from Which Sea Anemones Were Collected and at Which They Were Observed

\begin{tabular}{|c|c|c|c|c|}
\hline Site & Site Name & Latitude & Longitude & Species Recorded \\
\hline 1 & Bartolomé & -0.2800 & -90.5400 & Bu. grandis, Anth. nigrescens, Arachnanthus \\
\hline 2 & Cousins & -0.2370 & -90.5731 & Bu. grandis, T. panamensis \\
\hline 3 & Daphne Major & -0.4191 & -90.3775 & Bu. grandis \\
\hline 4 & Daphne Minor & -0.3946 & -90.3532 & Bu. grandis \\
\hline 5 & Darwin: Arch & 1.6725 & -91.9900 & Bu. grandis, T. panamensis, Antiparactis \\
\hline 6 & Española: Gardner Bay & -1.3442 & -89.6682 & Bu. grandis \\
\hline 7 & Fernandina: Punta Espinosa & -0.2704 & -91.4422 & Bu. grandis, Aiptasia \\
\hline 8 & Fernandina: Punta Mangle & -0.3716 & -91.3811 & Bu. grandis, Aiptasia, Bo. benedeni \\
\hline 9 & Floreana: Champion & -1.2395 & -90.3893 & Bu. grandis \\
\hline 10 & Floreana: Corona del Diablo & -1.2144 & -90.4238 & $\begin{array}{l}\text { Bu. grandis, T. panamensis, Aiptasia, Bo. } \\
\text { benedeni }\end{array}$ \\
\hline 11 & Floreana: Enderby & -1.2350 & -90.3655 & Bu. grandis \\
\hline 12 & Floreana: La Botella & -1.2904 & -90.4989 & Bu. grandis, T. panamensis \\
\hline 13 & Floreana: Las Cuevas, south & -1.2612 & -90.3603 & Bu. grandis, Anth. nigrescens, Bo. benedeni \\
\hline 14 & Floreana: Punta Cormorant & -1.2256 & -90.4195 & Bu. grandis \\
\hline 15 & Genovesa, entrance & 0.3019 & -89.9440 & Antiparactis \\
\hline 16 & Gordon Rocks & -0.5660 & -90.1406 & Bu. grandis, T. panamensis \\
\hline 17 & Guy Fawkes & -0.4989 & -90.5122 & T. panamensis \\
\hline 18 & Isabela: Caleta Iguana & -0.9945 & -91.4454 & Calliactis \\
\hline 19 & Isabela: Cape Marshall & -0.0171 & -91.2027 & Antiparactis \\
\hline 20 & Isabela: Las Marielas & -0.5996 & -91.0906 & Aiptasia \\
\hline 21 & Isabela: Playa Negra & -0.2231 & -91.3984 & Bu. grandis \\
\hline 22 & Isabela: Punta Albemarle & 0.1675 & -91.3358 & Bu. grandis, P. papillosa \\
\hline 23 & Isabela: Punta Moreno & -0.7024 & -91.3382 & Bu. grandis \\
\hline 24 & Isabela: Punta Vicente Roca & -0.0558 & -91.5604 & Bu. grandis, P. papillosa, Arachnanthus \\
\hline 25 & Isabela: Roca Redonda & 0.2719 & -91.6237 & Bu. grandis, Antiparactis \\
\hline 26 & Isabela: Tagus Cove & -0.2677 & -91.3723 & $\begin{array}{l}\text { Bu. grandis, Anth. nigrescens, T. panamensis, } \\
\text { Calliactis, Bo. benedeni }\end{array}$ \\
\hline 27 & Los Hermanos & -0.8485 & -90.7481 & Bu. grandis, Anth. nigrescens \\
\hline 28 & Marchena: Piedras Blancas & 0.3075 & -90.5371 & Bu. grandis \\
\hline 29 & Marchena: Punta Espejo & 0.3113 & -90.3984 & Anth. nigrescens, T. panamensis \\
\hline 30 & North Plaza & -0.5777 & -90.1565 & Bu. grandis \\
\hline 31 & Pinzón: Roca Onan & -0.5909 & -90.6860 & Bu. grandis, Anth. nigrescens, Anth. mariscali \\
\hline 32 & Pinzón, north shore & -0.5978 & -90.6874 & Bu. grandis, Anth. nigrescens \\
\hline 33 & Rabida & -0.3992 & -90.7046 & $\begin{array}{l}\text { Anth. nigrescens, T. panamensis, Bo. benedeni, } \\
\text { Arachnantbus }\end{array}$ \\
\hline 34 & San Cristobal: Punta Pitt & -0.6901 & -89.2690 & Bu. grandis \\
\hline 35 & San Cristobal: Roca Este & -0.8929 & -89.3619 & P. papillosa \\
\hline 36 & Santa Cruz: Academy Bay & -0.7500 & -90.3100 & $\begin{array}{l}\text { Bu. grandis, P. papillosa, Anth. nigrescens, } \\
\text { Anth. mariscali, T. panamensis }\end{array}$ \\
\hline 37 & Santa Cruz: Eden Islet & -0.5550 & -90.5372 & Bo. benedeni \\
\hline 38 & Santa Cruz, NE of Point Bowditch & -0.5172 & -90.4747 & Anth. mariscali \\
\hline 39 & Santa Cruz, NE side & -0.5838 & -90.1744 & Anth. mariscali \\
\hline 40 & Santa Cruz: Punta Estrada & -0.7609 & -90.3052 & Bu. grandis \\
\hline 41 & Santa Cruz: Tortuga Bay & -0.7647 & -90.3392 & $\begin{array}{l}\text { Bu. grandis, } P \text {. papillosa, Anth. nigrescens, } T \text {. } \\
\text { panamensis }\end{array}$ \\
\hline 42 & Santa Fe & -0.8000 & -90.0369 & Anth. mariscali, T. panamensis \\
\hline 43 & Santiago: Beagle Rocks & -0.4127 & -90.6279 & T. panamensis \\
\hline 44 & Santiago: James Bay, anchorage & -0.2413 & -90.8600 & Bo. benedeni \\
\hline 45 & South Plaza, north side & -0.5808 & -90.1631 & Anth. mariscali \\
\hline 46 & South Plaza, west end & -0.5794 & -90.1675 & Anth. mariscali \\
\hline 47 & Wolf, anchorage & 1.3787 & -91.8194 & Bu. grandis, T. panamensis, Calliactis \\
\hline 48 & Wolf, east side & 1.3870 & -91.8164 & Bu. grandis, T. panamensis \\
\hline
\end{tabular}


which belong to five families, occur on hard substrata; we found no burrowing actiniarians. The two species of cerianthids live burrowed into sand. The actiniarians Bunodosoma grandis (Verrill, 1869), Phymactis papillosa (Lesson, 1830), and Telmatactis panamensis (Verrill, 1869) and the cerianthid Botruanthus benedeni (Torrey \& Kleeberger, 1909) have an eastern Pacific distribution; the actiniarian Anthopleura mariscali Daly \& Fautin, 2004, appears to be endemic to the Galápagos Islands; and the actiniarians Anthopleura nigrescens (Verrill, 1928) and Calliactis "polypus" are broadly distributed in the Indo-West Pacific. Of those identified only to genus, the actiniarian Aiptasia and the cerianthid Aracbnanthus belong to widely distributed tropical genera; the other actiniarian, Antiparactis, belongs to a genus for which too little is known to establish geographic affinities. Not included in this inventory are members of another taxon of soft-bodied hexacorallians, order Zoanthidea: colonies occur on rock faces in the low intertidal and high subtidal, and subtidally on black coral. We have seen no members of order Corallimorpharia in the Galápagos.

Our inventory includes the most commonly encountered species from the intertidal zone and diving depths based on our own observations as well as those of Paul Humann (New World Publications, Inc.) and Ken Collins and Jenny Mallinson (University of Southampton, United Kingdom). Other species of sea anemones and possibly of cerianthids occur in shallow waters of the Galápagos Islands; we have collected and photographed specimens of actiniarians for which there was insufficient information to make a good identification. We provide black and white images of the animals dealt with in this article; color images of them will be included in a forthcoming field guide (C.P.H., unpubl. data), which is a companion to three already published (Hickman 1998, Hickman and Finet 1999, Hickman and Zimmerman 2000). A key to live animals follows detailed information that consists of appearance in life and preservation. Data on distribution are included in Table 1 as well as in the section concerned with each species. For com- prehensive information on the bibliography, distribution, synonymy, and other aspects of all species, see Fautin (2006).

\section{MATERIALS AND METHODS}

Our inventory is based largely on collections made during the course of nine visits to the Galápagos Islands by C.P.H. during the years 1998-2006 and one by D.G.F. in 2001 but also includes information from collections made by Richard N. Mariscal in 1964. Specimens were collected with the permission of the Government of Ecuador; those collected by C.P.H. are the property of the Charles Darwin Research Station; those collected by R. N. Mariscal are in the collection of the Division of Invertebrate Zoology, University of Kansas Natural History Museum and Biodiversity Research Center (кUNHM).

Specimens were collected by hand intertidally or by diving, examined alive, then preserved in $10 \%$ formalin in seawater or in ethanol. Histological sections $8 \mu \mathrm{m}$ thick were stained with hematoxylin and eosin (Humason 1979). Cnidae were measured in squash preparations at $1,000 \times$ with differential interference contrast optics. Cnidae terminology is that of Mariscal (1974).

Locality records for each species are keyed to details in Table 1 and depicted in Figure 1.

RESULTS AND DISCUSSION

Order Actiniaria

Family Actinitidae

Bunodosoma grandis (Verrill, 1869)

Figures 2-5

Live APPEARANCE (Figure 2): Column about as long as wide, although it can lengthen somewhat; entirely covered in nonadhesive small vesicles (as is also true of Phymactis papillosa). An individual typically red, orange, brown, or pink; some individuals have alternating longitudinal stripes of lighter and darker hue. Clonal, as evidenced by likecolored individuals tightly packed together and by division scars on some animals; one individual was observed (in June) dividing 


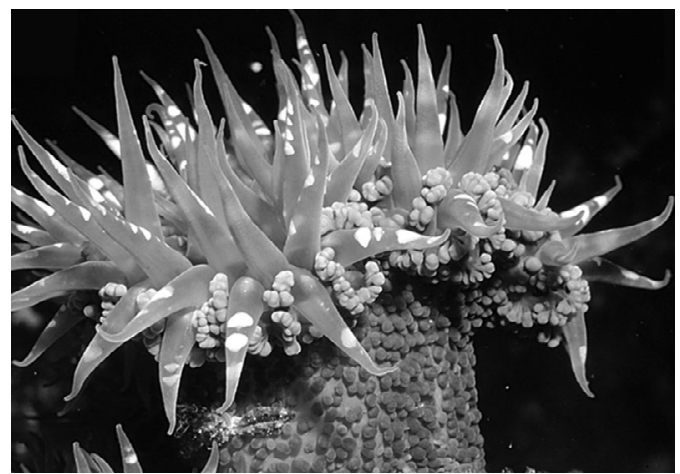

Figure 2. Bunodosoma grandis (Verrill, 1869). Whole animal, alive. Photograph by C.P.H.

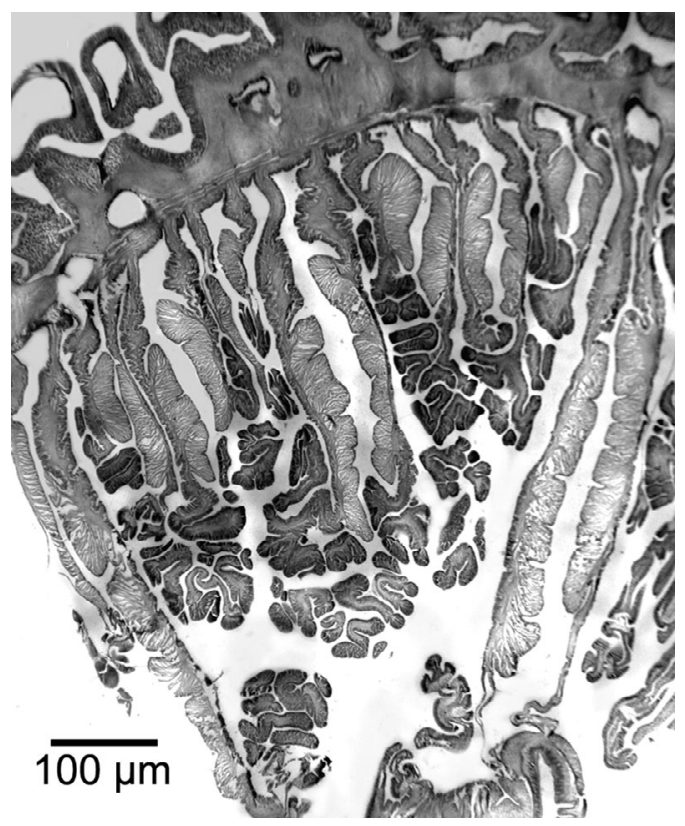

Figure 3. Bunodosoma grandis (Verrill, 1869). Cross section through column.

longitudinally. Average size about $20 \mathrm{~mm}$ column diameter with a wider, undulating oral disk (30-40 mm typically); largest animals seen about $30 \mathrm{~mm}$ basal diameter, $60 \mathrm{~mm}$ oral disk diameter. Oral disk commonly brown but may have short, white radial lines halfway between mouth and tentacles, which are pointed, relatively short (to half oral disk

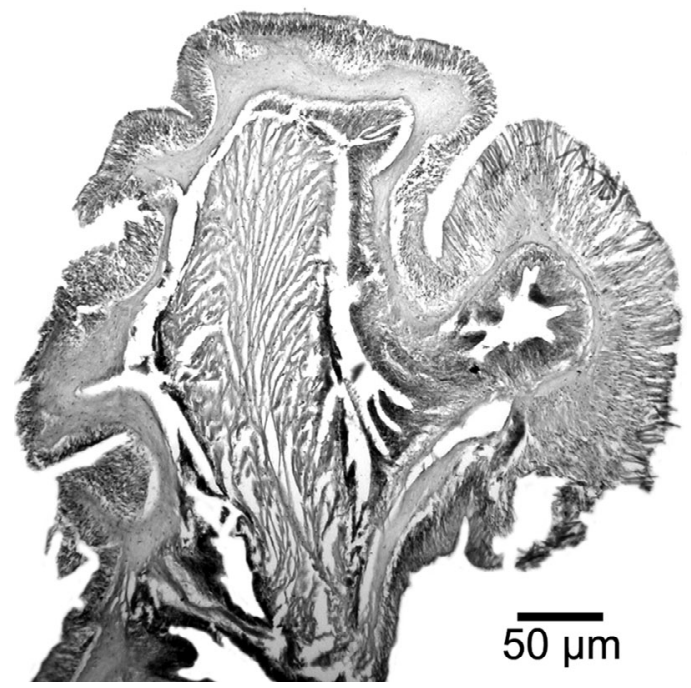

Figure 4. Bunodosoma grandis (Verrill, 1869). Marginal sphincter muscle.

diameter in length), and very sticky. Tentacles near edge of oral disk; inner longer than outer ones; they may be colorless, gray, or brown, and those of some individuals have deep pink tips and/or white or gray splotches or bands on oral surface. Acrorhagi form white, pink, tan, or pale orange fingerlike projections at distal end of column. Out of water, animal contracts to a conical mound only slightly shorter than its expanded height; it also contracts under strong illumination. Pedal disk typically pinkish but may be red, with mesenterial insertions visible as dark (red) lines.

HABiтAT: The most conspicuous species of sea anemone we encountered in the Galápagos, occurring from midintertidal zone to at least $20 \mathrm{~m}$; especially abundant in the shallow subtidal. Adheres to hard substrata, commonly rock. However, has been recorded from "wreckage," we found a small individual attached to the inside of the broken test of a heart urchin lying on sand, and a photo by Jonathan Green shows it attached to the shell of a hermit crab. Especially in the midintertidal zone, commonly in crevices and under overhangs; subtidal individuals on exposed surfaces, some attached to or surrounded by 

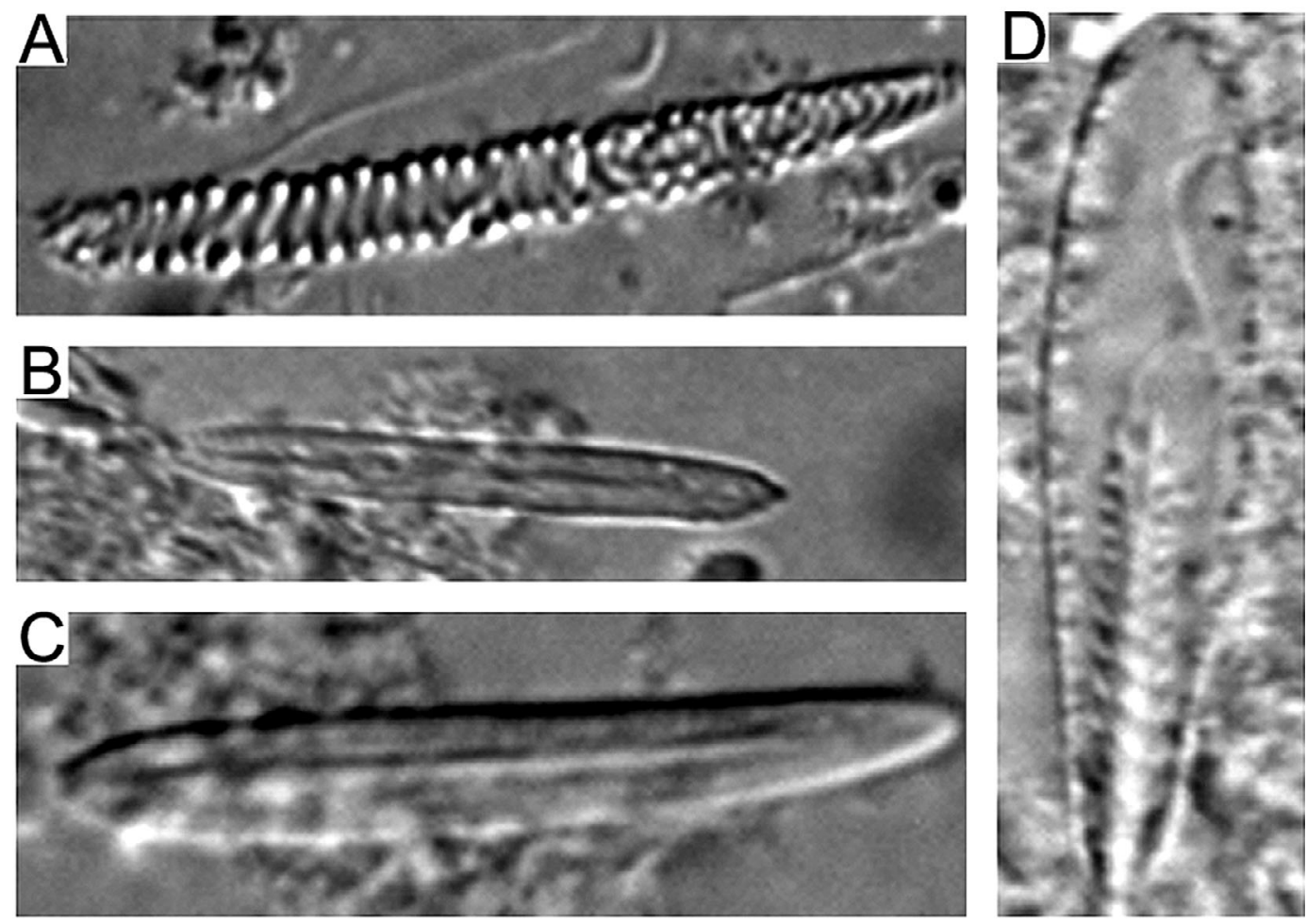

\section{$10 \mu \mathrm{m}$}

Figure 5. Bunodosoma grandis (Verrill, 1869). Cnidae; see Table 2 for types and sizes.

encrusting sponges. From low intertidal to about $5 \mathrm{~m}$, may carpet substratum; shallower and deeper individuals more scattered and generally smaller.

Detailed aCcount: Column vesicles about $1 \mathrm{~mm}$ diameter, appear globular but, in life, can be pulled to a length of more than $5 \mathrm{~mm}$; each vesicle a deeper shade than body wall, and vesicle tip typically a brighter shade, but some red vesicles with green cast. We interpret as division scars longitudinal strips of column the width of several typical vesicles in which the vesicles are small or absent. Tentacles may be absent or stubby at distal end of division scar. Tentacles longitudinally fluted when collapsed in life and in some preserved specimens. Acrorhagi at distal end of fingerlike projections; aboral side of projec- tion bears one to several vesicles that contain basitrichs like rest of column; oral side bears single or compound acrorhagus that overhangs deep fosse and that contains holotrichs and basitrichs. Mesenteries hexamerously arranged in four cycles with two symmetrical siphonoglyphs. Cnidom: spirocysts, basitrichs, microbasic $p$-mastigophores. Figures 3 and 4 show diagnostic histological details for the species; Figure 5 depicts the cnidae, which are inventoried in Table 2.

Notes: The description of this species appeared in Verrill (1869a). We conclude that McMurrich (1893) misidentified specimens of this species collected on the Albatross expedition to the Galápagos as Antholoba reticulata, a name he used presumably because both species have a textured (rather 
TABLE 2

Distribution and Size of Cnidae of Bunodosoma grandis (Verrill, 1869)

\begin{tabular}{|c|c|c|c|}
\hline Cnidae & Dimensions & $n$ & $N$ \\
\hline \multicolumn{4}{|l|}{ Tentacles } \\
\hline Spirocysts $(\mathrm{A})^{a}$ & $14.4-38.0 \times 1.8-4.0(4.3)$ & 62 & $4 / 4$ \\
\hline Basitrichs (B) & $8.5-16.2 \times 1.2-3.2$ & 14 & $2 / 4$ \\
\hline Basitrichs (C) & $(19.9) 21.7-30.6(32.5) \times 2.3-4.0$ & 61 & $4 / 4$ \\
\hline \multicolumn{4}{|l|}{ Actinopharynx } \\
\hline Basitrichs (B) & $8.8-14.1 \times 1.2-2.0$ & 11 & $2 / 2$ \\
\hline Basitrichs (C) & (16.6) $19.1-29.7 \times 2.0-4.4$ & 36 & $2 / 2$ \\
\hline \multicolumn{4}{|l|}{ Mesenterial Filaments } \\
\hline Basitrichs (B) & (11.2) $13.7-17.5 \times 1.7-2.9$ & 26 & $3 / 3$ \\
\hline Basitrichs (C) & $20.4-35.2(36.3) \times 2.2-5.5$ & 17 & $2 / 3$ \\
\hline Microbasic p-mastigophores (D) & $(20.1) 22.6-28.8(32.3) \times 4.1-5.7$ & 21 & $2 / 3$ \\
\hline \multicolumn{4}{|l|}{ Column $\quad P$ to } \\
\hline Basitrichs (B) & $(14.1) 15.1-20.6(22.1) \times 1.8-3.1(3.8)$ & 29 & $2 / 2$ \\
\hline Basitrichs (C) & $22.9-30.2 \times 2.4-4.4$ & 25 & $2 / 2$ \\
\hline
\end{tabular}

Note: Letters refer to components of Figure 5. Dimensions of cnidae are length $\times$ width in $\mu \mathrm{m}, n=$ total number of capsules measured, $N=$ proportion of animals studied that contained a particular type of cnida.

${ }^{a}$ Some seem to have spirocysts of two size categories, but the line between the categories differs among individuals.

than smooth) column, and their oral disk cannot lie flat, so, especially when the animal is slightly contracted, the oral disk undulates to the point that it can appear lobed (Fautin 1984). The name $A$. reticulata is a junior synonym of $A$. achates, a species that is abundant and widespread in southern South America and into the Subantarctic (Fautin 1984). In a publication on the anemones of Montemar, Valparaiso, Chile, Carter Verdeilhan (1965) listed $A$. achates as occurring in the Galápagos; she provided no reference for this information, but it is likely to be McMurrich's (1893) report because she listed $A$. reticulata as a synonym of $A$. achates, and McMurrich (1893) was among works on Chilean anemones she cited. A fundamental difference between the species is that $A$. reticulata has a mesogleal sphincter muscle whereas that of $B$. grandis is endodermal. We find no evidence that $A$. achates occurs in the Galápagos and interpret all records of it as misidentifications of B. grandis.

RECORDS IN THE GALÁPAGOS ISLANDS: The most widespread species we found: Bartolomé (1), Cousins (2), Daphne Major (3), Daphne Minor (4), Darwin (5), Española (6), Fernandina (7, 8), Floreana (9-14), Gordon
Rocks (16), Isabela (21-26), Los Hermanos (27), Marchena (28), North Plaza (30), Pinzón $(31,32)$, San Cristobal (34), Santa Cruz $(36,40,41)$, Wolf $(47,48)$.

Distribution OTHER THAN THE GaLÁPAGOS ISLANDS: Nicaragua: Corinto (Verrill 1869a), Rio Brito (Verrill 1869b). Panama: Bay of Panama (Verrill 1869a). Peru: Paita (Verrill 1869a), Zorritos (Verrill 1869a).

\section{Phymactis papillosa (Lesson, 1830)}

Figure 6

live appearance (Figure 6): Column, oral disk, and tentacles of every individual found solid bright red. As in Bunodosoma grandis, column entirely covered with small vesicles. Column length and diameter in all animals examined about $50 \mathrm{~mm}$; pedal disk about equal to column diameter but oral disk, which lies flat, somewhat wider. Sticky, bluntly pointed tentacles short (to about a quarter oral disk diameter in length) and longitudinally fluted when contracted or collapsed. Tentacles arise from marginal half of oral disk.

habitat: The most distinctive species of sea anemone encountered in the Galápagos. 


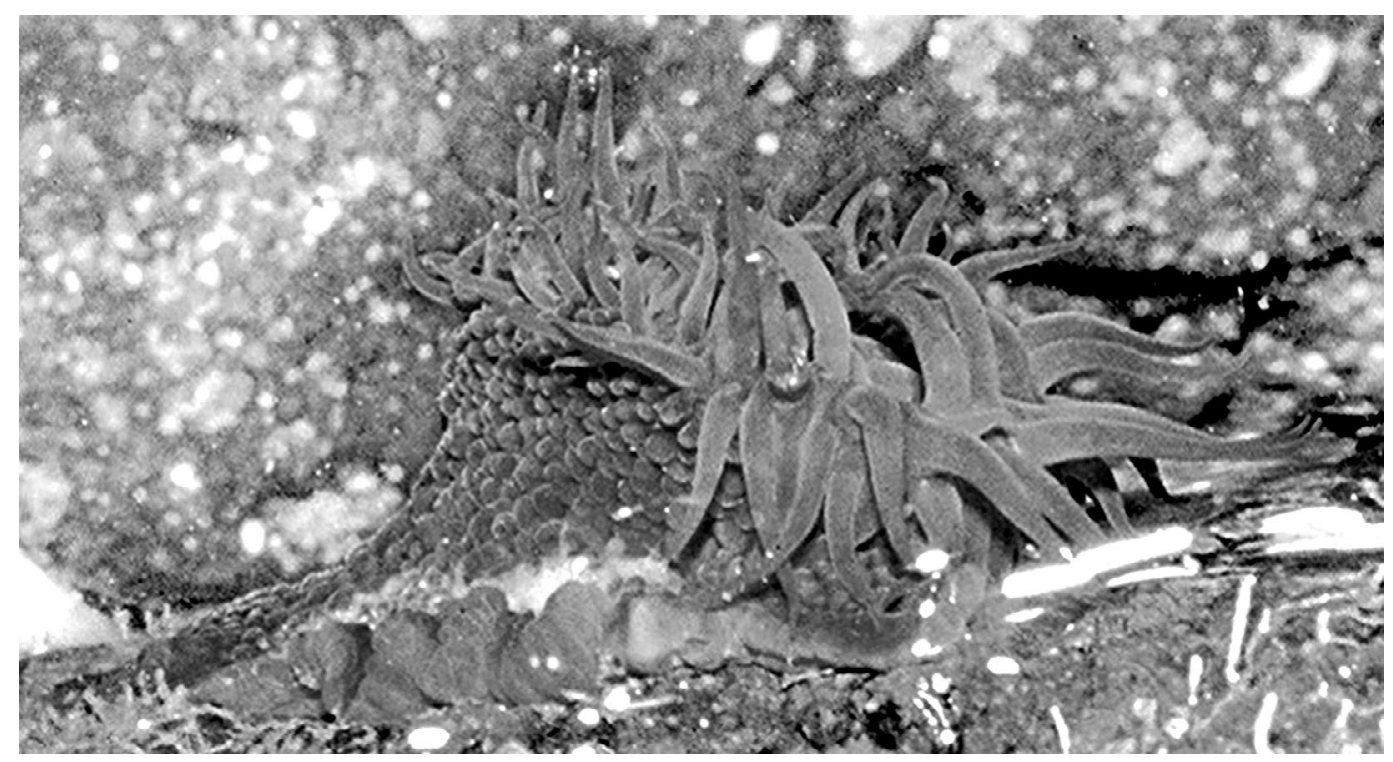

Figure 6. Phymactis papillosa (Lesson, 1830). Whole animal, alive. Photograph by C.P.H.

Not common; inconspicuous because it attaches to underside of rocks in the lowermost intertidal and uppermost subtidal zones.

Detailed account: Column vesicles about $1 \mathrm{~mm}$ diameter, appear globular; tip of each vesicle same color as body wall: a lighter shade of red than the rest of the vesicle. Pedal disk pinkish with mesenterial insertions visible as dark (red) lines. Acrorhagi at margin: each with several bumps on aboral side, red-tipped pink projection on oral side overhangs deep fosse; contain holotrichs and basitrichs (uncommon small ones and common large ones). Actinopharynx pink. Cnidom: spirocysts, basitrichs, holotrichs, microbasic $p$-mastigophores.

NOTES: This is likely the species of which Darwin remarked "Color uniform most beautiful Lake Red" (Keynes 2000:288). Although on the Pacific coast of South America this species occurs in a wide variety of colors (Häussermann 2004), in the Galápagos Islands only red animals occur; red animals predominate in Mexico (Daly, pers. obs., as cited by Häussermann 2004). In a revision of this species, Häussermann (2004) provided a com- plete synonymy and extensive diagnosis, including data on histology and cnidae, so we do not include those details. The cnidae of specimens from the Galápagos Islands are generally somewhat larger than those reported by Häussermann, and we cannot confirm the presence of microbasic amastigophores in the actinopharynx and mesenterial filaments.

RECORDS IN THE GALÁPAGOS ISLANDS: Throughout the central archipelago: Isabela (22, 24), San Cristobal (35), Santa Cruz (36, 41).

DisTRIBUTION OTHER THAN THE gaLÁpagos islands: Chile: Arica to Archipelago de los Chonos (Häussermann 2004), Bahía de Ancud (Carlgren 1959), Easter Island (Carlgren 1959, Zamponi 1977), Iquique (McMurrich 1904, Carlgren 1959), Juan Fernández Island (Carlgren 1922), Talcahuano (Verrill 1869a), Tocopilla (Carlgren 1959), Valparaiso (Dana 1846, 1859, Carlgren 1959, Carter Verdeilhan 1965). Mexico: Baja California (Carlgren 1951, Daly in Häussermann 2004). Nicaragua (Zamponi 1977). Panama: Pearl Islands (Verrill 1869a). Peru: Callao (Dana 


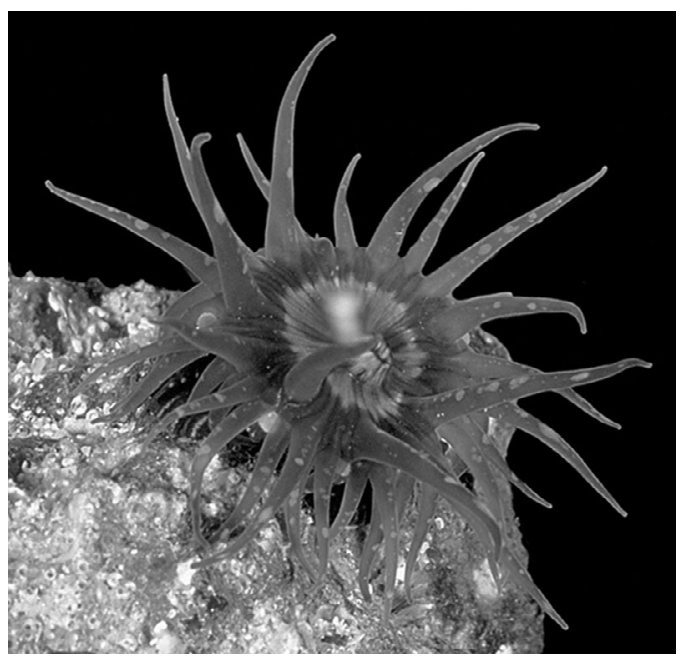

Figure 7. Anthopleura nigrescens (Verrill, 1928). Whole animal, alive. Photograph by C.P.H.

1846), Lima (Verrill 1869a). Records from Argentina under this name are erroneous (Häussermann 2004).

Anthopleura nigrescens (Verrill, 1928)

Figure 7

live appearance (Figure 7): Cylindrical column dark with longitudinal rows of lightcolored, adhesive verrucae; in individuals with reddish tentacles, verrucae rust-colored. Proximal verrucae more numerous and conspicuous than distal ones, giving many animals the appearance of having radial light stripes around the base. Pedal disk pinkish. Maximum pedal disk diameter about $20 \mathrm{~mm}$; a typical animal $10 \mathrm{~mm}$ across oral and pedal disks, and about equally long. A contracted animal forms a flattened dome about half its expanded height. Column can be entirely or only partly covered with gravel; when an ani$\mathrm{mal}$ is disturbed, some verrucae retain gravel grains (in contrast to $A$. mariscali, which sheds them). Tentacles occupy outer half of oral disk; the longest (inner) ones about as long as oral disk is wide. Each tentacle tapers to a point; gray, with red cast in many individuals; may have transverse or longitudinal white bands or splotches on oral face. In an individual with solid gray oral disk, longitudinal white lines of tentacles may extend across disk to mouth, which is circular; alternatively, entire disk may be white, with some animals having one or more dark radii. Clonal, judging by density and proximity of individuals and by groupings of unusually colored individuals (those with colorless or greenish tentacles); one individual was observed (in June) dividing longitudinally.

haвiтat: Anthopleura nigrescens may rival Bunodosoma grandis in abundance but much less conspicuous, being smaller and bedecked with camouflaging gravel that adheres to the verrucae. Occurs throughout the intertidal zone attached to rocks; at the very highest levels confined to cracks and the underside of rocks, lower it is more exposed. In places sympatric with $A$. mariscali, but $A$. nigrescens extends lower intertidally; even high in the intertidal, $A$. mariscali may be absent where $A$. nigrescens occurs. Rather easily removed from substratum (in contrast to $A$. mariscali) either because its adherence to the rocks is not tight or because it attaches to smooth rocks; lives in broader cracks than does $A$. mariscali. In places (e.g., Bartolomé), it appears that animals may be entirely covered by shifting beds of sand (as is true of $A$. elegantissima in the Northeast Pacific [Hand 1975]).

DETAIled ACCOUnT: Verrucae larger than they appear because center is lightcolored. More rows of verrucae proximally than distally: alternate rows extend only half to a third column length. Acrorhagi at margin, complex, light-colored (white or with reddish or yellowish cast); 18 counted in average-sized animal. 4-6 siphonoglyphs. Cnidom: spirocysts, basitrichs, holotrichs, microbasic $p$-mastigophores.

NOTES: Because specimens of this animal from the Galápagos Islands conform in all respects to those from Hawai'i studied by Dunn (1974) and to those from there and elsewhere studied by England (1987), we do not provide micrographs, images of cnidae, or an inventory of cnidae. Note that what Dunn (1974) termed atrichs are now considered holotrichs. 


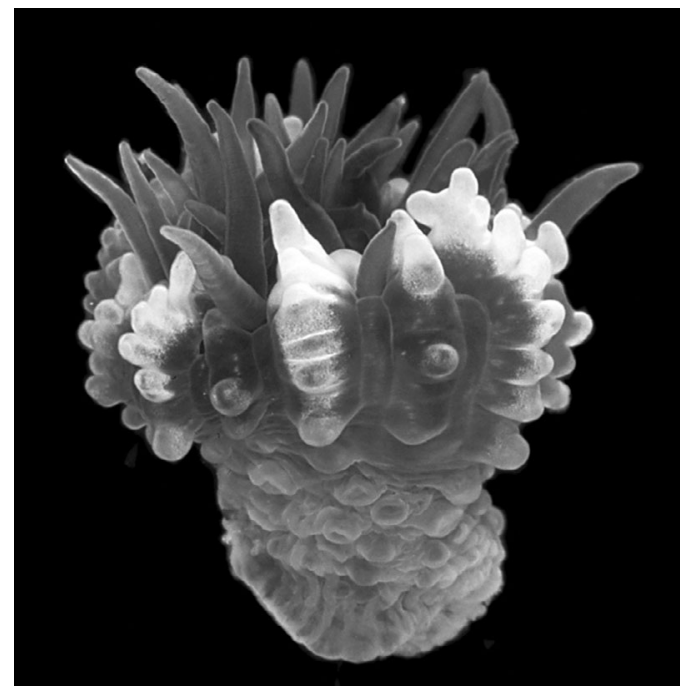

Figure 8. Anthopleura mariscali Daly \& Fautin, 2004. Whole animal, alive. Photograph by C.P.H.

RECORDS IN THE GALÁPAGOS ISLANDS: Bartolomé (1), Floreana (13), Isabela (26), Los Hermanos (27), Marchena (29), Pinzón (31, 32), Rabida (33), Santa Cruz (36, 41).

DISTRIBUTION OTHER THAN THE GALÁPAgOS ISLANDS: Hong Kong (England 1987, 1992). India: Bombay (Parulekar 1968), Cochin (England 1987), Mahim (Parulekar 1968). Japan: Hokkaido (Uchida 1938), Mutsu Bay (Uchida 1938). Korea: Geojedo Island (Song and Lee 1998), Korea Strait (Uchida 1938, Song 1992, Song and Lee 1998). Marshall Islands: Enewetak Atoll (Cutress and Arneson 1987). USA: Hawai'i (Verrill 1928, Dunn 1974, Cutress 1977, England 1987).

Anthopleura mariscali Daly \& Fautin, 2004 Figure 8

Live appearance (Figure 8): Column cylindrical, orange near pedal disk, darkening distally. Column may be entirely or partly covered with gravel that adheres to verrucae; when animal is disturbed or collected, gravel is shed (in contrast to Anthopleura nigrescens, which retains at least some of it). Large, adhesive verrucae same color as column arrayed in longitudinal rows; distalmost verru- cae elongate, abut one another, terminal one extending from the margin nearly as far as a marginal tentacle, from which it can be distinguished by being blunter; distalmost verrucae stark white, making an animal appear to have radial light stripes around its margin. Maximum oral disk diameter about $15 \mathrm{~mm}$; maximum pedal disk diameter about half that; column typically $7 \mathrm{~mm}$ long. A contracted animal forms a flattened dome about half its expanded height; center appears red because the deep red tentacles remain partly visible. Tentacles occupy outer half of oral disk; the longest (inner) ones about as long as oral disk radius. A medium-sized animal has 48 tentacles; each tapers to dull point, may have a narrow green longitudinal stripe. Oral disk translucent brownish with mesenterial insertions visible as light lines through it; oral stripes of tentacles may run across oral disk to mouth, which is circular. Pedal disk pinkish. Clonal, judging by density and proximity of individuals.

нав ітат: From the highest intertidal zone to at least midintertidal; where it has been found, sympatric with $A$. nigrescens, but distribution is patchier than that of $A$. nigrescens. Attaches to rocks, typically in cracks. Difficult to remove from substratum (in contrast to $A$. nigrescens) either because it adheres tightly to the rocks or because it attaches to rough rocks; large individuals more difficult to remove than small ones. Typically lives in narrower crevices than does $A$. nigrescens.

Detailed account: Marginal structures communicating with primary and secondary endocoels more conspicuous than the others: distalmost 4-5 verrucae prominent, white, protrude far beyond margin. Higherorder endocoels have only 1-2 distal, lessprominent verrucae; exocoels lack marginal projections. Verrucae smaller, less prominent proximally. Three to four cycles of hexamerously arranged mesenteries with strong, restricted retractor muscles; parietal muscle narrow, with short pennon. Cnidom: spirocysts, basitrichs, holotrichs, microbasic $b$ mastigophores, microbasic $p$-mastigophores.

Notes: This seems to be a Galápagos endemic. Because it was so thoroughly described by Daly and Fautin (2004), we do 


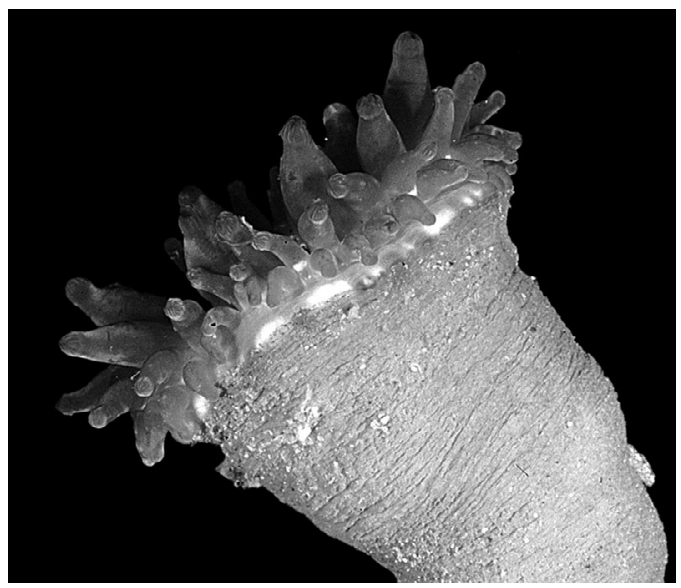

FIgUre 9. Telmatactis panamensis (Verrill, 1869). Whole animal, alive. Photograph by C.P.H.

not provide micrographs, images of cnidae, an inventory of cnidae, nor a list of material examined.

RECORDS IN THE GALÁPAGOS ISLANDS: Pinzón (31), Santa Cruz $(36,38,39)$, Santa Fe (42), South Plaza (45, 46).

Distribution other than the galápagos ISLANDS: None known.

\section{Family Isophelliddae}

\section{Telmatactis panamensis (Verrill, 1869)}

Figures 9-12

live appearance (Figure 9): Oral and pedal disks of a typical individual $10-15 \mathrm{~mm}$ diameter, column somewhat broader or narrower; the most proximal portion of column may be narrower than pedal disk, so when collected animal may tear at this thin "stem." Column about as long as or somewhat less than basal diameter. Scapus, to which gravel adheres its entire length, darker orange in color proximally than distally; distalmost part of column a short, thick-walled scapulus. Column can extend to about twice as long as wide but can contract to somewhat shorter than wide. White acontia may be emitted through scapus. Actinopharynx may be paler orange than column; two symmetrical siphonoglyphs, each may have white marking at its intersection with oral disk. Central oral

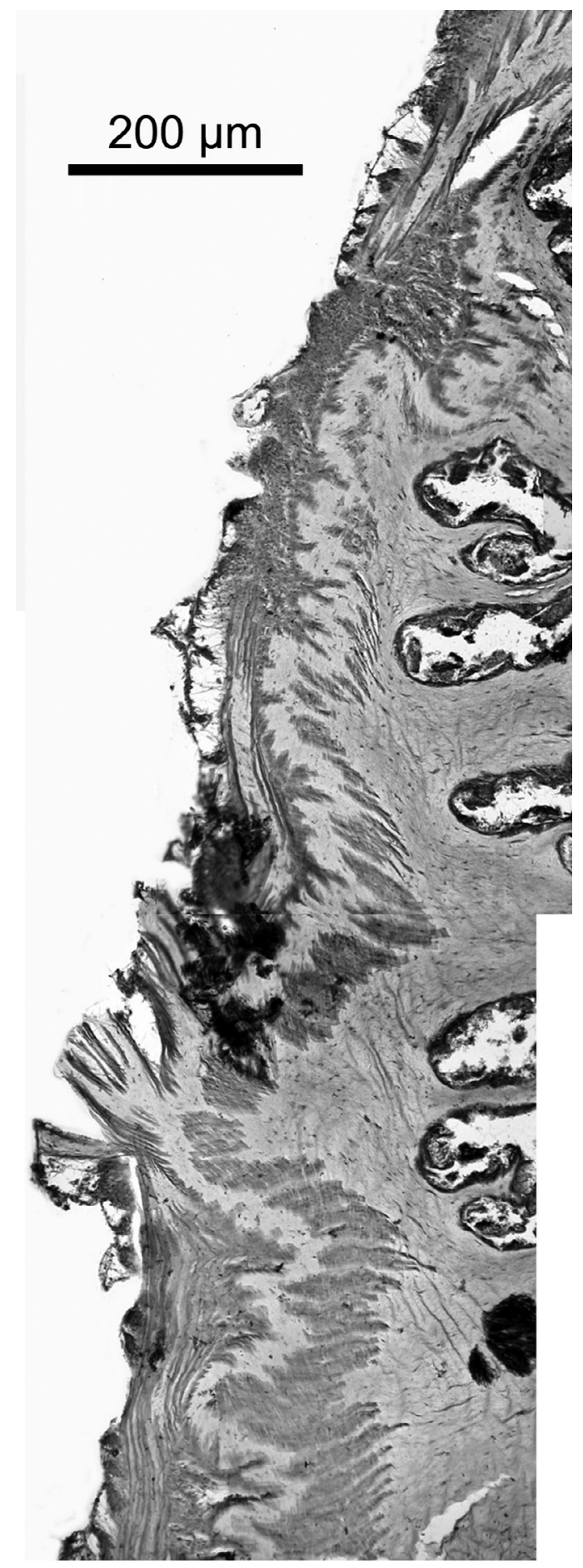

Figure 10. Telmatactis panamensis (Verrill, 1869). Marginal sphincter muscle. 


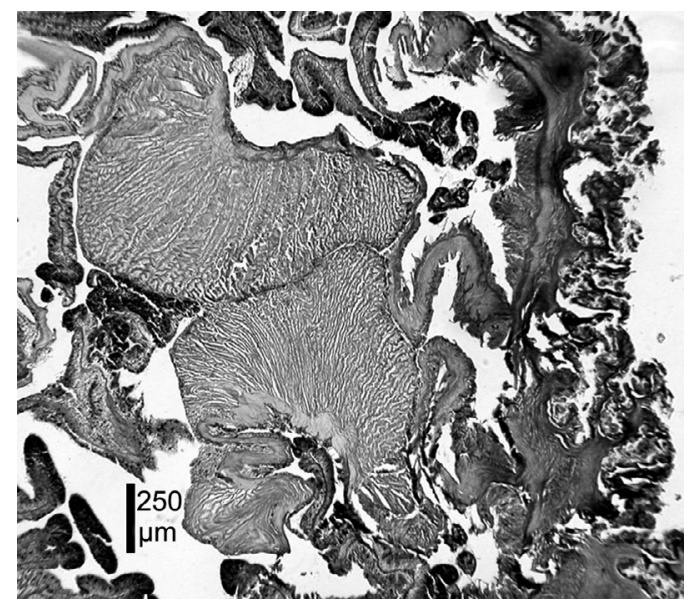

FIgURe 11. Telmatactis panamensis (Verrill, 1869). Cross section of pair of retractor muscles.

disk tentacle-free; each digitiform tentacle may be blunt or swollen at its end. A typicalsized animal has 48 tentacles ranging from a few millimeters long (the most marginal ones) to about $10 \mathrm{~mm}$ (the primary ones, nearest the mouth). Tentacles vary in color and pattern even in one individual: a typical tentacle has a proximal white crossband or white frosting distal to which tentacle is greenish or brown; distalmost part may be solid red or grayish with red splotches or narrow longitudinal sinuous red lines; or entire tentacle may be deep brown with only hints of red distally or have white bands on the oral face or white rings. Oral disk can be solid in color, be frosted white immediately around the tentacles, or have a complex radial pattern of red, green, and white.

haвiтAт: Low intertidal to at least the greatest diving depths $(35 \mathrm{~m})$ under rocks, commonly attached to large cobbles or shells.

Detailed account: Telmatactis is a species-rich genus (Doumenc et al. 1989); each species can vary in color and other respects. Therefore, it is possible that more than one species of the genus occurs in the Galápagos. However, preserved specimens we examined represent a single species. They agree with the detailed account of $T$. panamensis by Carlgren (1951) and the description of Phellia rapanuiensis by Carlgren (1922).
Points of agreement include size, gross morphology, histological details of mesenterial retractor and marginal sphincter muscles, and size and distribution of cnidae. We therefore synonymize the species Carlgren (1949) listed as T. rapanuiensis (Carlgren, 1922) and T. panamensis (Verrill, 1869). Doumenc et al. (1989) referred to them as T. rapanuensis (Carlgren, 1920) and T. panamensis (Verrill, 1869), respectively. Figures 10 and 11 show diagnostic histological details for the species. Cnidom: spirocysts, basitrichs, microbasic $p$-mastigophores, microbasic amastigophores. Figure 12 depicts the cnidae inventoried in Table 3; we identified as basitrichs those from the mesenterial filaments termed microbasic amastigophores by Carlgren (1951) (Figure 12B). We found, as did Carlgren (1951), that larger individuals have larger cnidae; we found that width increases less markedly than length with animal size.

NoTEs: Verrill (1899) proposed the genus Phelliopsis for this species, stating that it resembles a species of Phellia but lacks acontia; we agree with Carlgren (1951) that Verrill overlooked them. The treatment of Phelliopsis Panamensis Ver. in Verrill (1899) is confused: the section header refers to Figures 37 and $37 a$ whereas the text refers to parts of figs. 30; fig. 30 does not illustrate this species, and neither the original journal publication nor the offprint of it includes a fig. 37.

In a worldwide inventory of Telmatactis, Doumenc et al. (1989) concluded that, except for two species, members of the genus are entirely littoral. We found that T. panamensis, which was previously known only littorally, extends much deeper; Wirtz (1996) studied T. cricoides in a depth range of 0-62 m. Other species that have been known only from the littoral may also extend deeper.

RECORDS IN THE GALÁPAGOS ISLANDS: Cousins (2), Darwin (5), Floreana (10, 12), Gordon Rocks (16), Guy Fawkes (17), Isabela (26), Marchena (29), Rabida (33), Santa Cruz (36, 41), Santa Fe (42), Santiago (43), Wolf $(47,48)$.

Distribution OTHER THAN THE gaLÁPAGOS ISLANDs: Chile: Easter Island (Rapanui) (Carlgren 1922). Mexico: Baja California (Carlgren 1951). Panama (Verrill 1869a). 

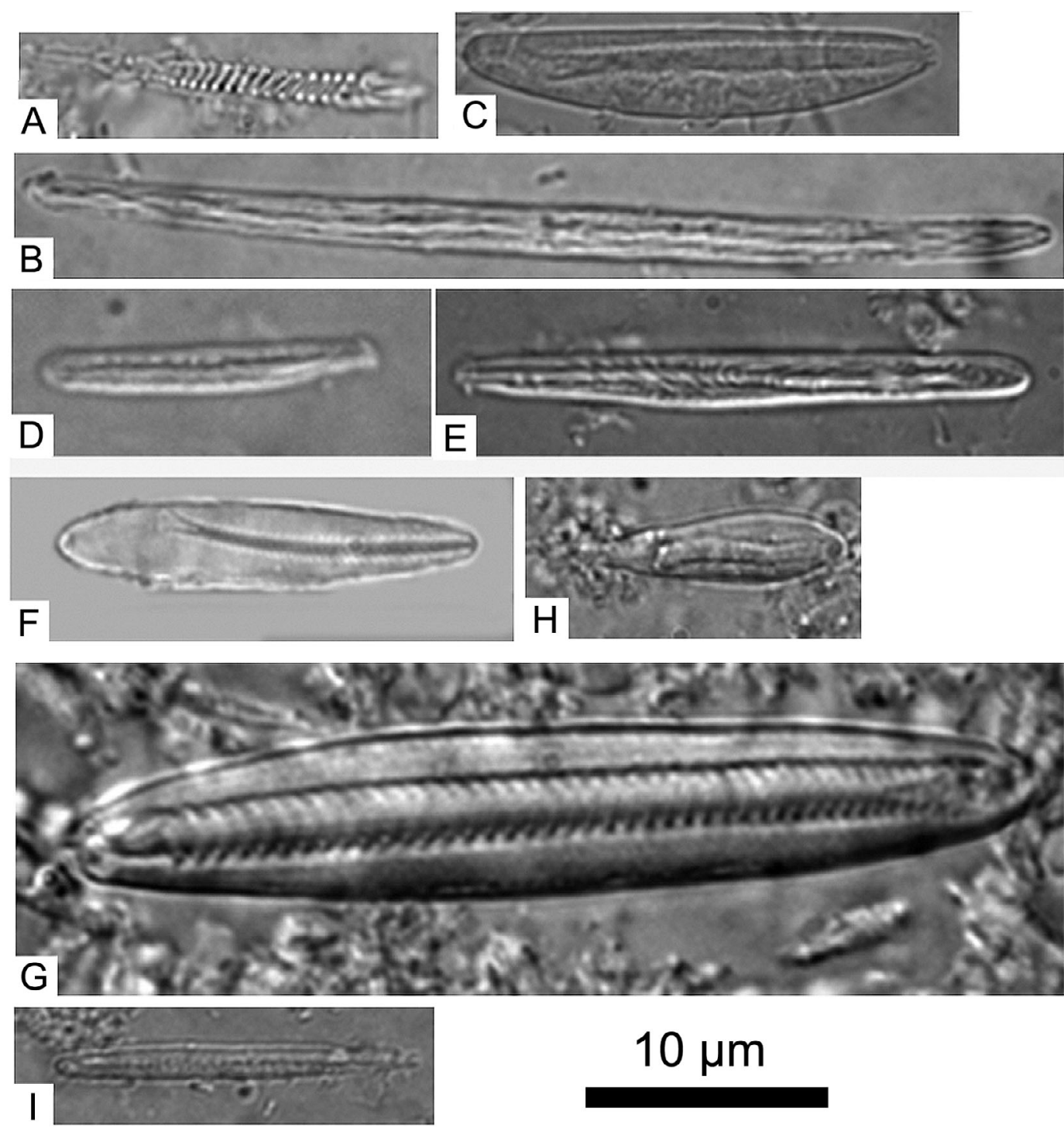

\section{$10 \mu \mathrm{m}$}

Figure 12. Telmatactis panamensis (Verrill, 1869). Cnidae; see Table 3 for types and sizes.

\section{Family Aiptasildae}

Aiptasia sp.

Figures 13, 14

LIVE APPEARANCE (Figure 13): Oral disk of a typical individual $15-20 \mathrm{~mm}$ diameter, frosted white on light, translucent brown; mouth, which may be situated on an oral cone, typically white encircled with a brown ring; mesenterial insertions (typically 24 pairs) may be visible through oral disk as dark lines. Because animals live in densely packed clones, some numbering in the thousands of individuals, oral disk is all that is typically visible. Narrow, tapered tentacles about as long as radius of oral disk occur only at margin; typically straight but, especially in smaller indi- 
TABLE 3

Distribution and Size of Cnidae of Telmatactis panamensis

\begin{tabular}{|c|c|c|c|}
\hline Cnidae & Dimensions & $n$ & $N$ \\
\hline \multicolumn{4}{|l|}{ Tentacles } \\
\hline Spirocysts $(\mathrm{A})^{a}$ & $17.2-45.7 \times 1.8-4.6$ & 67 & $6 / 6$ \\
\hline Basitrichs (B) & $31.1-64.9(69.5) \times(1.8) 2.1-3.9$ & 109 & $6 / 6$ \\
\hline Microbasic $p$-mastigophores (C) & (29.6) $31.9-37.9 \times 4.3-6.3(7.2)$ & 20 & $3 / 6$ \\
\hline \multicolumn{4}{|l|}{ Actinopharynx } \\
\hline Basitrichs (D) & $13.1-18.9 \times 1.6-3.2$ & 25 & $2 / 3$ \\
\hline Basitrichs (E) & $24.1-36.2(40.5) \times(1.7) 2.1-4.7$ & 53 & $3 / 3$ \\
\hline Microbasic $p$-mastigophores $(\mathrm{F})$ & $(26.8) 27.6-31.3(33.1) \times 3.8-5.2(5.9)$ & 11 & $2 / 3$ \\
\hline Microbasic p-mastigophores (G) & (35.3) 42.0-62.4 (69.7) × 6.7-11.0 (12.7) & 44 & $3 / 3$ \\
\hline \multicolumn{4}{|l|}{ Mesenterial Filaments } \\
\hline Basitrichs (D) & $12.1-27.6(29.5) \times 1.1-3.3$ & 103 & $6 / 6$ \\
\hline Basitrichs (B) & (36.7) $44.0-53.1 \times 2.5-3.7$ & 8 & $2 / 6$ \\
\hline Microbasic $p$-mastigophores $(\mathrm{H})$ & $12.6-24.1(25.1) \times 3.5-6.2$ & 50 & $3 / 6$ \\
\hline Microbasic $p$-mastigophores (G) & $57.2-77.2(81.9) \times(9.4) 10.4-15.9$ & 21 & $4 / 6$ \\
\hline \multicolumn{4}{|l|}{ Acontia } \\
\hline Basitrichs (I) & $19.6-28.8(31.9) \times 1.8-3.8$ & 65 & $4 / 4$ \\
\hline Microbasic p-mastigophores (G) & $(55.8) 57.7-72.3 \times 9.3-13.7(14.7)$ & 33 & $4 / 4$ \\
\hline \multicolumn{4}{|l|}{ Column (Scapulus) } \\
\hline Basitrichs (D) & $13.9-25.9 \times 2.6-4.1$ & 52 & $4 / 4$ \\
\hline Microbasic amastigophores ${ }^{b}$ & $(17.7) 18.7-24.2(26.1) \times 5.0-6.0(6.5)$ & 14 & $2 / 4$ \\
\hline
\end{tabular}

Note: Letters refer to components of Figure 12. Dimensions of cnidae are length $\times$ width in $\mu \mathrm{m}, n=$ total number of capsules measured, $N=$ proportion of animals studied that contained a particular type of cnida.

a Some seem to have spirocysts of two size categories, but the line between the categories differs among individuals.

${ }^{b}$ This type of nematocyst was encountered rarely (as is obvious from the numbers) and all capsules had been discharged. No tubule was seen to extend from the shaft.

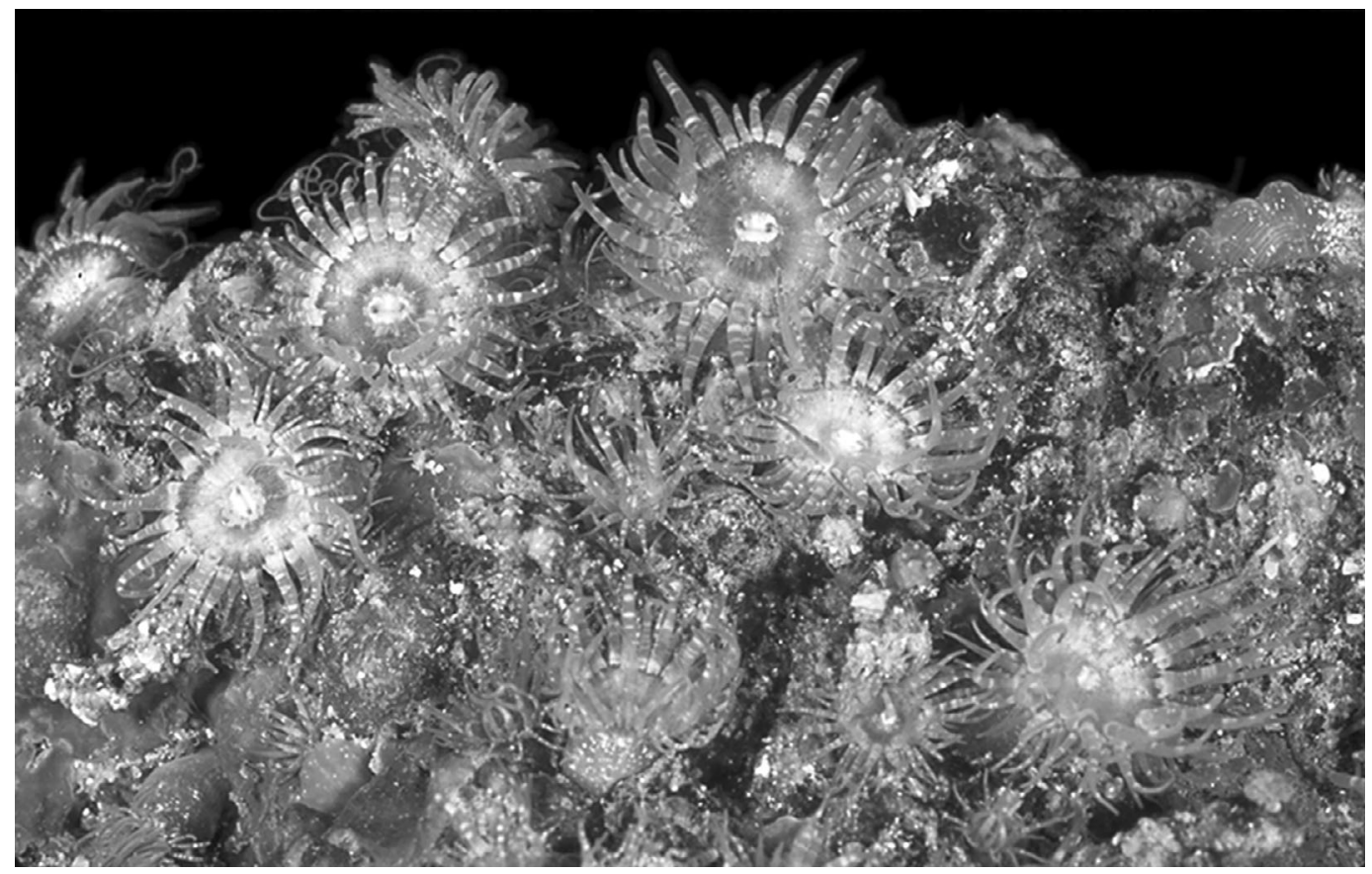

Figure 13. Aiptasia sp. Whole animal, alive. Photograph by C.P.H. 

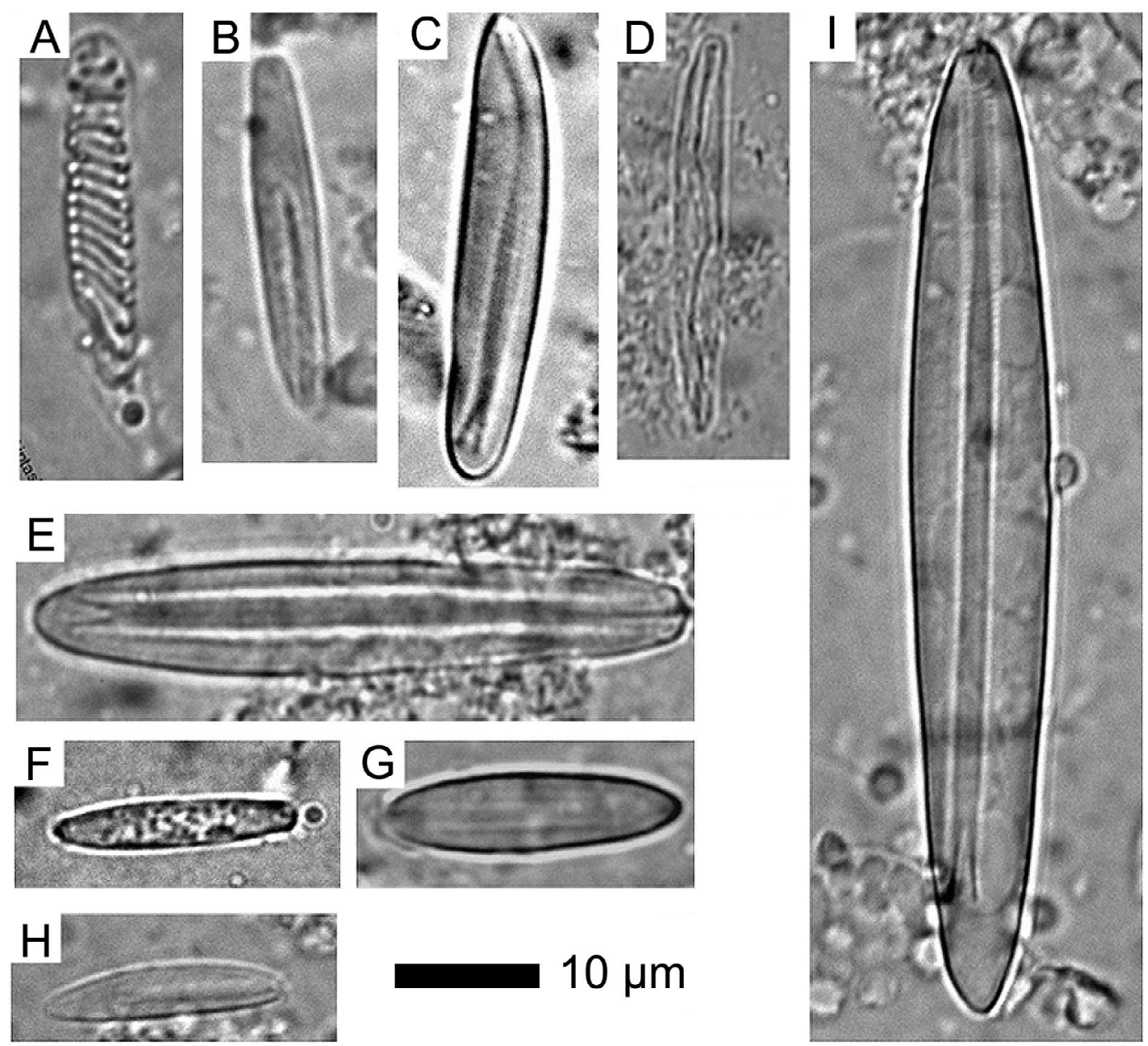

Figure 14. Aiptasia sp. Cnidae; see Table 4 for types and sizes.

viduals, may be kinky; number around 70 in medium-sized individuals. Tentacles same brown color as oral disk; some have white frosting around base and/or white spots or transverse bars on oral face or may be ringed. Animal hourglass shaped: oral and pedal disks about equal diameter, column narrower. Column extensible, typically about as long as oral disk is wide; brown in color, darker distally than proximally, presumably due to zooxanthellae being denser at distal than at proximal end. In some individuals, white frosting on distal end is spotty in midcolumn and diminishes farther proximally; if visible, mesenterial insertions light lines; some intermesenterial spaces may be darker than others, giving the animal a faintly striped appearance. Ring of 6-12 cinclides occurs about midscapus, which constitutes most of column length; each cinclis opens atop a discrete, nipplelike bulge in column wall. Figure 14 depicts the cnidae inventoried in Table 4.

навітат: On bedrock, stones, and shells to $5 \mathrm{~m}$.

detailed account: Aiptasia, a genus with more than a dozen nominal species, the validity of most of which is unknown (Fautin 2006), is a name that has been applied to many 
TABLE 4

Distribution and Size of Cnidae of Aiptasia sp.

\begin{tabular}{|c|c|c|c|}
\hline Cnidae & Dimensions & $n$ & $N$ \\
\hline \multicolumn{4}{|l|}{ Tentacles } \\
\hline Spirocysts (A) & $11.3-30.0 \times 2.0-3.5(4.4)$ & 21 & $4 / 4$ \\
\hline Basitrichs (B) & $13.3-22.9 \times 1.8-3.7$ & 36 & $4 / 4$ \\
\hline Microbasic $p$-mastigophores (C) & $26.1-37.4(38.9) \times 4.0-6.2$ & 46 & $4 / 4$ \\
\hline \multicolumn{4}{|l|}{ Actinopharynx } \\
\hline Basitrichs (D) & $20.8-25.4(26.3) \times 2.5-3.3$ & 12 & $1 / 1$ \\
\hline Microbasic $p$-mastigophores (E) & $32.5-33.8(35.2) \times 4.4-5.5(6.4)$ & 8 & $1 / 1$ \\
\hline \multicolumn{4}{|l|}{ Mesenterial Filaments } \\
\hline Basitrichs $(\mathrm{F})$ & $(10.7) 11.3-13.1(13.8) \times 1.9-3.7$ & 13 & $1 / 2$ \\
\hline Basitrichs $(\mathrm{G})$ & $12.0-15.0 \times 3.1-4.1(4.6)$ & 12 & $1 / 2$ \\
\hline Microbasic $p$-mastigophores $(\mathrm{H})$ & $12.1-16.3(17.8) \times 2.5-4.7$ & 18 & $1 / 2$ \\
\hline Microbasic $p$-mastigophores (E) & $33.7-44.2 \times(4.2) 4.6-6.4$ & 24 & $2 / 2$ \\
\hline \multicolumn{4}{|l|}{ Acontia } \\
\hline Basitrichs (D) & $(21.5) 22.6-28.8(30.4) \times(1.4) 2.0-3.4$ & 37 & $3 / 3$ \\
\hline Microbasic $p$-mastigophores (I) & (61.6) $62.8-75.5 \times 6.2-8.9(9.6)$ & 27 & $3 / 3$ \\
\hline \multicolumn{4}{|l|}{ Column } \\
\hline Basitrichs (B) & $13.8-17.8(19.9) \times 2.2-3.5$ & 19 & $2 / 3$ \\
\hline Basitrichs (G) & $16.0-21.2 \times 3.0-5.3$ & 32 & $3 / 3$ \\
\hline Microbasic $b$-mastigophores $(\mathrm{H})$ & (18.3) $19.2-25.2 \times(5.1) 5.7-6.9$ & 10 & $2 / 3$ \\
\hline
\end{tabular}

Note: Letters refer to components of Figure 14. Dimensions of cnidae are length $\times$ width in $\mu \mathrm{m}, n=$ total number of capsules measured, $N=$ proportion of animals studied that contained a particular type of cnida.

small, nondescript anemones. For example, the species Entacmaea medusivora was referred to as $A$. pulchella, despite the animals differing in fundamental ways (Fautin and Fitt 1991). Based on nematocyst complement and sizes (Table 4, Figure 14), the animals collected in 2001 definitely belong to the genus Aiptasia but not to the species $A$. pulchella, which was described from Japan by Carlgren (1943) and is the name most commonly applied to animals attributed to this genus in the Pacific.

Notes: This species was reported in the Galápagos as new during the 1997-1998 El Niño disturbance (C.P.H., pers. obs.), when the Islands received warm water of low salinity for a prolonged period. It is the cause of the "anemone barrens" reported by Okey et al. (2003, 2004). It, or something resembling it, had been noted previously (P. Humann, pers. comm.). There is no way of knowing, without specimens, if the animals belong to the same species.

RECORDS IN THE GALÁPAGOS ISLANDS: Fernandina (7, 8), Floreana (10), Isabela (20).

\section{Family Hormathindae}

\section{Calliactis "polypus"}

Figures 15, 16

Live APPEARANCE (Figure 15): Adheres to gastropod shell inhabited by a hermit crab; more than one individual may be attached to a single shell. Typical pedal disk ovoid, about 10 by $30 \mathrm{~mm}$ in two specimens measured. Column smooth; distal part mottled brown to beige, with prominent white cinclides distal to limbus; region between cinclides and limbus white, with brown lines indicating mesenterial insertions. Typically 100 or more long, conical, beige to white tentacles.

навітат: From shallow water to at least maximum scuba diving depths. The crustacean symbiont of all individuals for which an identification was made is Dardanus sinistripes.

detailed account: Column not differentiated into capitulum and scapus; distal end without cuticle. Pedal disk ovoid, circular, or drawn out in one plane; limbus faintly striped at mesenterial insertions. Cinclides not easily 


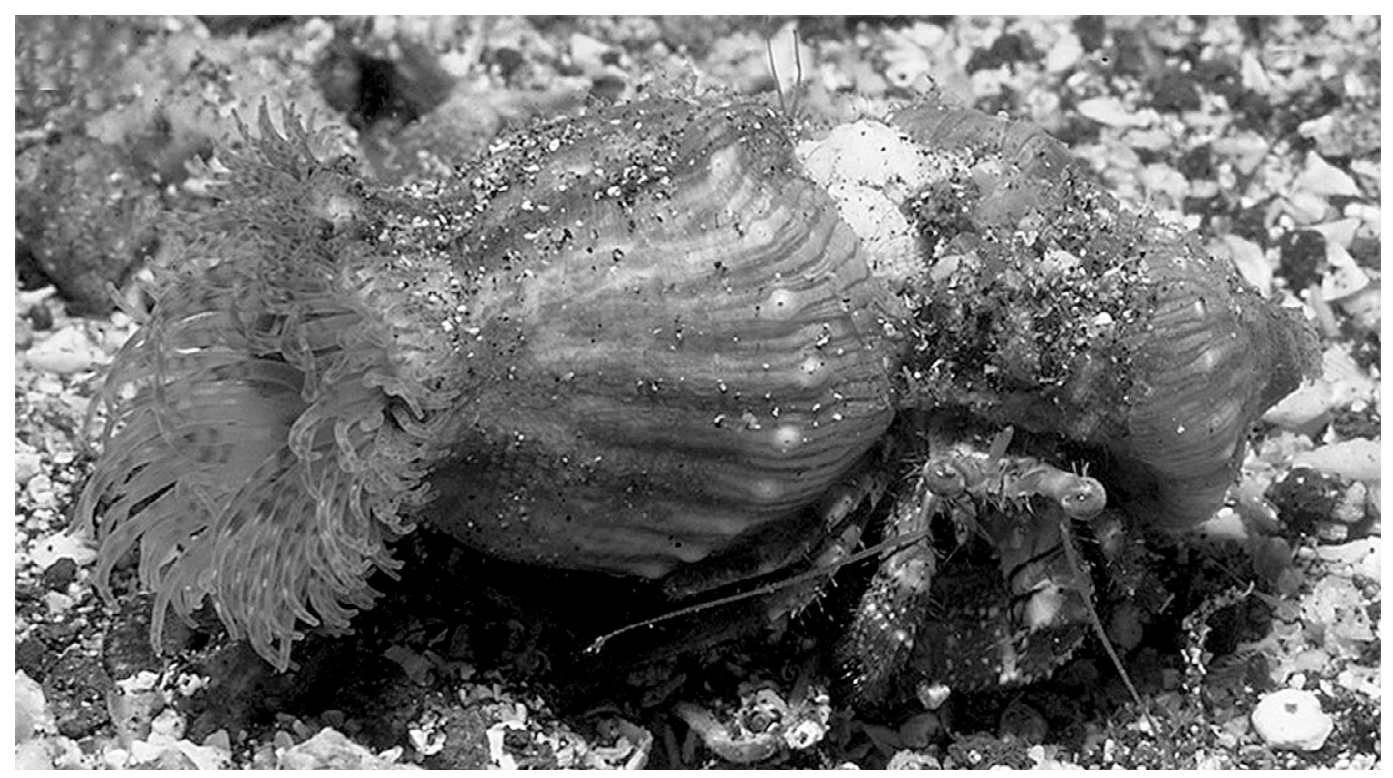

Figure 15. Calliactis "polypus." Whole animal, alive. Photograph by Paul Humann.

detected in preserved specimens, few clearly visible between larger mesenteries just distal to limbus. No fosse. Tentacles more numerous than mesenteries, slightly darker than column in one specimen. Strong mesogleal marginal sphincter. All examined specimens have four cycles of hexamerously arranged mesenteries: those of first cycle perfect and sterile, all others imperfect, those of second and third cycles fertile. Retractor muscles diffuse. Cnidom: spirocysts, basitrichs, holotrichs, microbasic $p$-mastigophores. Figure 16 depicts the cnidae inventoried in Table 5.

NOTES: Based on similarities in anatomy and cnidom, England (1971, 1987) synonymized with Priapus polypus Forsskål, 1775, the species Actinia decorata Dana, 1846; Adamsia miriam Haddon \& Shackleton, 1893; Calliactis sinensis Verrill, 1869; and (in part) C. armillatas Verrill, 1928. As a result, C. polypus
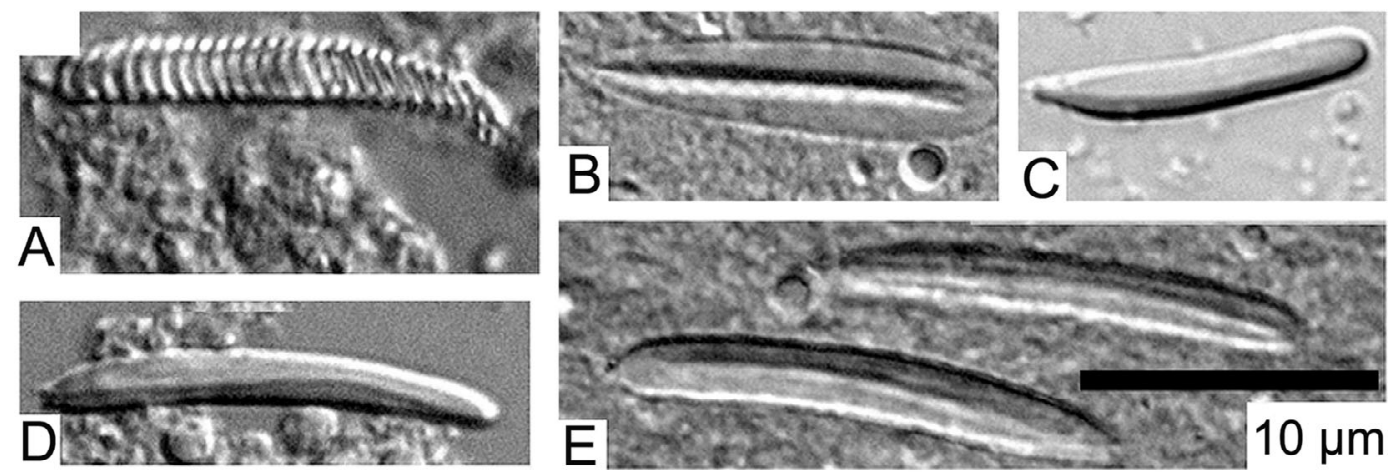

Figure 16. Calliactis "polypus." Cnidae; see Table 5 for types and sizes. 
TABLE 5

Distribution and Size of Cnidae of Calliactis "polypus"

\begin{tabular}{llll}
\hline \hline Cnidae & \multicolumn{1}{c}{ Dimensions } & $n$ & $N$ \\
\hline Tentacles & & & \\
$\quad$ Spirocysts (A) & $18.3-26.0 \times 1.9-3.4(3.8)$ & 24 & $2 / 2$ \\
$\quad$ Basitrichs (B) & $20.1-26.0 \times 1.9-2.7(3.0)$ & 30 & $2 / 2$ \\
Acontia & $20.4-27.8 \times 2.0-2.9$ & 36 & $2 / 2$ \\
$\quad$ Basitrichs (C) & $11.9-16.7 \times 1.4-2.8$ & 28 & $2 / 2$ \\
Mesenterial Filaments & $18.0-24.0 \times 3.3-5.3$ & 21 & $2 / 2$ \\
$\quad$ Basitrichs (E) & Microbasic p-mastigophores (D) & & \\
\hline
\end{tabular}

Note: Letters refer to components of Figure 16. The actinopharynx of both specimens was too macerated for cnidae preparations, and the thin layer of column ectoderm had been sloughed off. Dimensions of cnidae are length $\times$ width in $\mu \mathrm{m}, n=$ total number of capsules measured, $N=$ proportion of animals studied that contained a particular type of cnida.

(Forsskål, 1775) is the most widespread species of Calliactis, having been reported from the Red Sea and the Atlantic, Indian, and $\mathrm{Pa}$ cific Oceans. The component populations are variable in size of cnidae, coloration, and small details of anatomy, so, although they form a continuum that is difficult to subdivide (England 1971), we consider it likely that these populations do not all belong to a single species. We therefore place the specific epithet in quotation marks. The size of cnidae in Table 5 falls within the ranges given by England (1971) for C. polypus.

This is presumably the species of anemone most frequently seen attached to the shell of a hermit crab in the Galápagos, but it is not the only one-see habitat notes for Bunodosoma grandis.

RECORDS IN THE GALÁPAGOS ISLANDS: Isabela $(18,26)$, Wolf (47).

DISTRIBUTION OTHER THAN THE GALÁPAgOS ISLANDS: Aden (England 1971). Australia: Great Barrier Reef, Low Isles (Carlgren 1950a,b), New South Wales (Carlgren 1950a). Cape Verde Islands (Hertwig 1882). Christmas Island (England 1987). Kenya: Mombassa (England 1987). Maldive Islands (England 1987). Malay Straits (England 1987). Marshall Islands: Enewetak Atoll (Cutress and Arneson 1987). Red Sea (Klunzinger 1877). South Africa: Durban (Carlgren 1938). Tanzania: Masion and Bawi Islands, Tumbatu (Carlgren 1900). Tuamotu Archipelago (Dana 1846, 1859). USA: Hawai'i (Verrill 1928).

\section{Family Actinostolidae}

\section{Antiparactis sp.}

Figure 17

live appearance (Figure 17): Column smooth, without fosse; yellowish; except at oral end, with irregularly shaped brownish patches that are dark at center, lightening peripherally, giving animal a leopard-spotted appearance; in contracted individuals, patches may form irregular vertical rows. Expanded animal hourglass shaped, flaring at oral and pedal ends to maximum $\sim 20 \mathrm{~mm}$ diameter and $15 \mathrm{~mm}$ length; in contraction, low, domed, with spreading pedal disk irregular in outline and about as wide as animal is long. Flat or slightly concave oral disk translucent cream with mesenterial insertions visible as slightly darker lines; mouth central, lacking lips; two symmetrical siphonoglyphs. Tentacles marginal, number about 60; uniformly creamy yellow, slender, taper to point; innermost ones longest, about equal to oral disk diameter.

навітAт: Typically gregarious, with specimens of various sizes abutting one another, adhering to a hard substratum such as rocks, shells, and barnacle tests, but commonly cylindrical objects such as echinoid spines or gorgonian or antipatharian skeletons. Common at 20-25 m depth.

Detailed account: Pedal disk of animals attached to a cnidarian skeleton can secrete a papery, coppery coating over the 


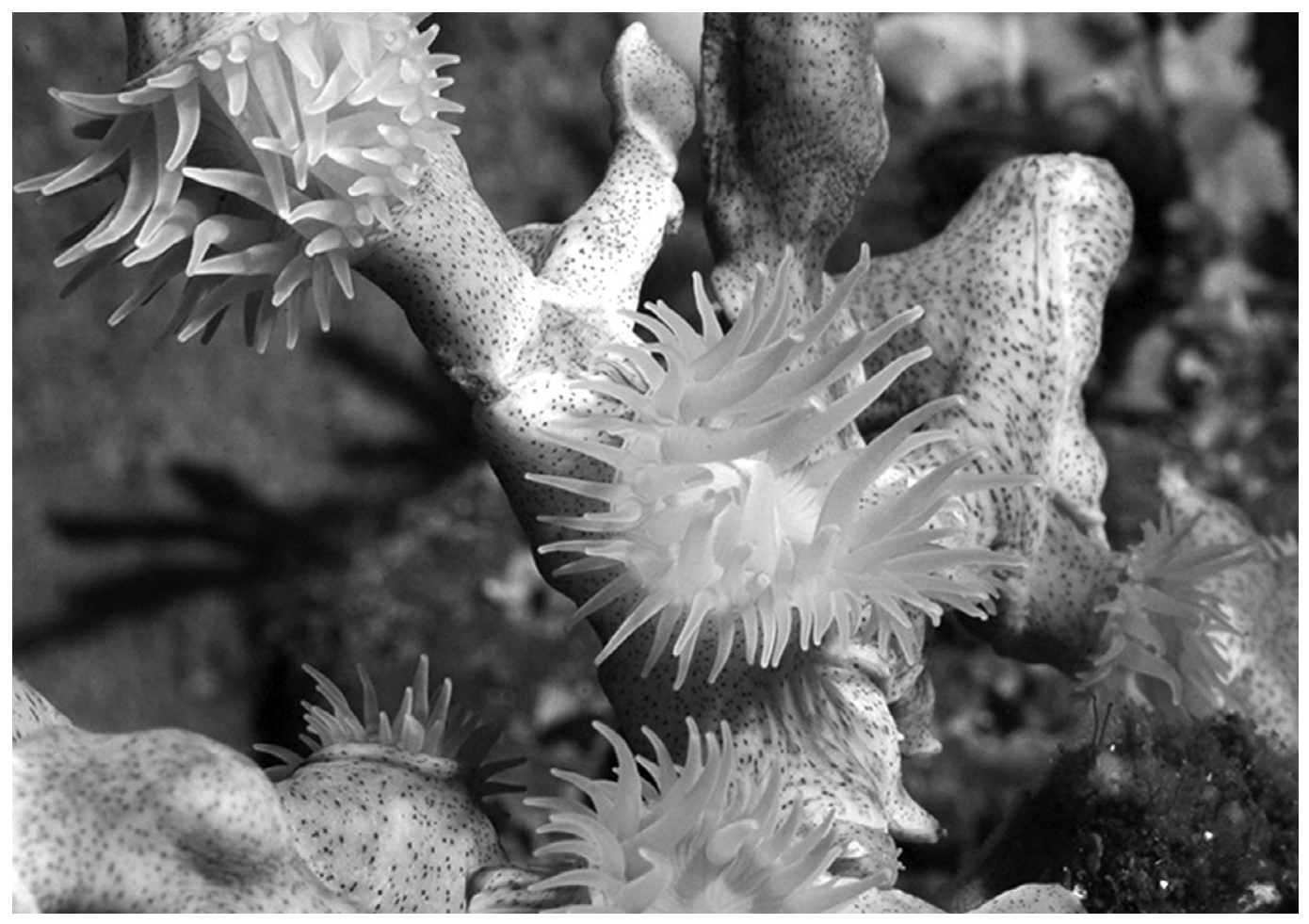

Figure 17. Antiparactis sp. Whole animal, alive. Photograph by Graham Edgar.

object; secretion of those attached at a branching point spans the angle between branches. Column beige and spots gray in preservation. Short capitulum abuts oral disk. Tentacles, which can be blunt in preservation, in three cycles.

Notes: These specimens resemble in size, color, and habitat those reported by McMurrich (1893) as Paractis lineolata (Dana) that were collected at 47 fathoms [86 m] in Panama by the Albatross, and those he identified (McMurrich 1904) as Pycnanthus lineolatus (McMurrich) from a depth of 30 fathoms [55 m] at Juan Fernández Island, Chile. The description attributed to Couthoy by Dana (1846) of Actinia lineolata was for a species collected at low water in Orange Harbour, Tierra del Fuego, by the U.S. Exploring Expedition; as McMurrich (1904) discussed, it is quite clearly a different species from the one reported by McMurrich (1893, 1904). The taxonomy and nomenclature of this animal have yet to be resolved.

RECORDS IN THE GALÁPAGOS ISLANDS: Darwin (5), Genovesa (15), Isabela $(19,25)$.

\section{Order Ceriantharia \\ Suborder SPIRUlaria \\ Family BotruCNidiferidae}

Botruanthus benedeni (Torrey \& Kleeberger, 1909)

\section{Figure 18}

LIVE APPEARANCE (Figure 18): Large animal with 160-180 or more marginal tentacles and about an equal number of labial ones. Marginal tentacles arrayed in at least four pseudocycles: those of the inner pseudocycles to 150 (or even 200?) $\mathrm{mm}$ long, but outer 


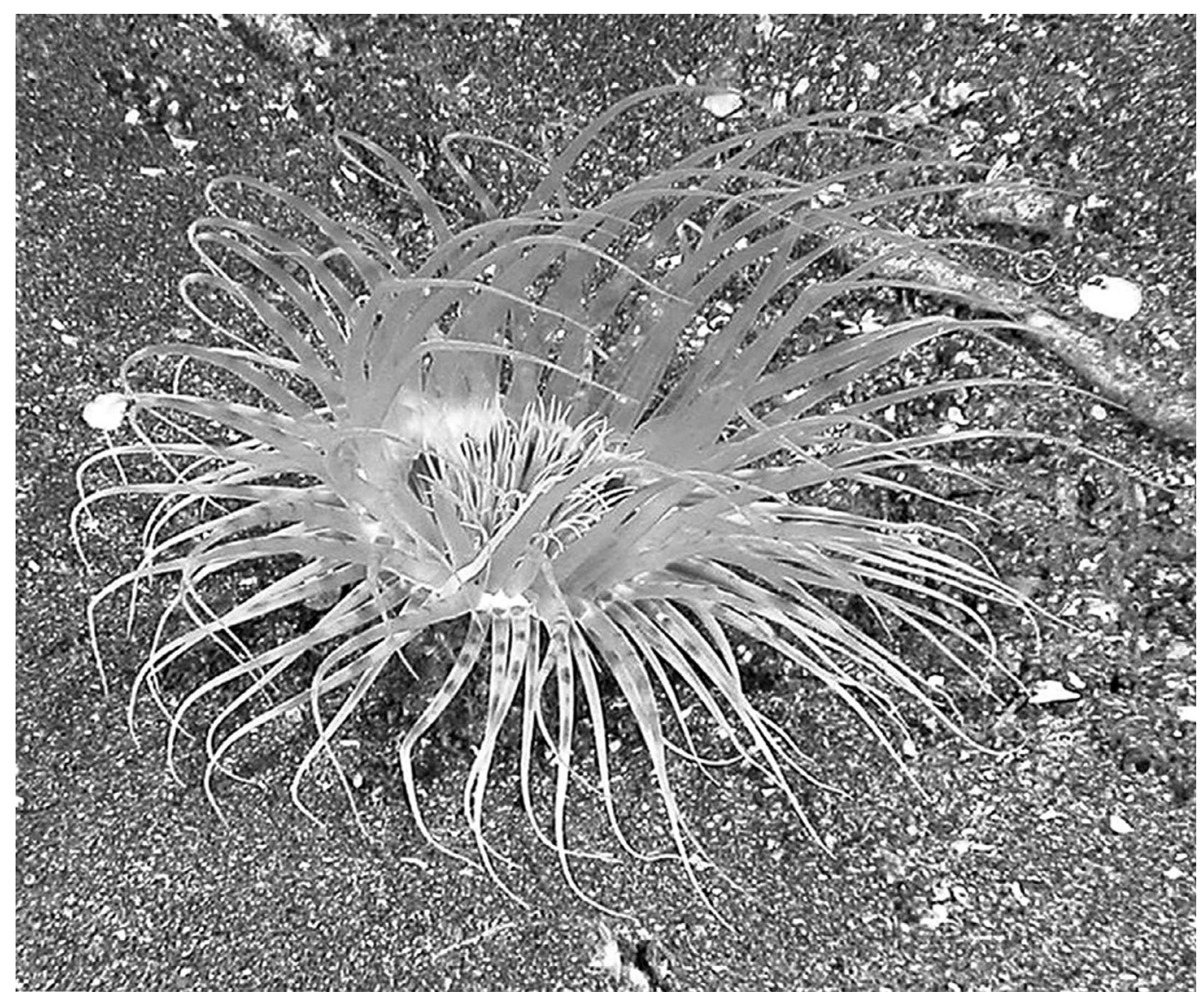

Figure 18. Botruanthus benedeni (Torrey \& Kleeberger, 1909). Oral end of animal in situ. Photograph by C.P.H.

ones much shorter. Labial tentacles may hide mouth and even the rather broad oral disk. At least two color varieties in the Galápagos Islands: (1) marginal tentacles dark purplish violet, some outer ones somewhat darker than inner, which may appear to have several dark purple bands, each actually a group of irregularly shaped dots; labial tentacles same color as outer marginal ones, each with longitudinal stripe along oral face; (2) marginal tentacles light gray or light violet, each with several darker bands; labial tentacles light brown to nearly white; oral disk may be darker than tentacles. Intermediate forms likely to exist. Column generally same color as outer marginal tentacles. Tube long, grayish, with thin wall (3-4 $\mathrm{mm})$; may be covered with scattered debris; never projects above surface of substratum. Commensal phoronid Phoronis australis not reported from tubes of $B$. benedeni.

навітAт: Burrowed into sand at 2-30 m depth.

Detailed aCcount: First protomesenteries (directives) sterile, short, devoid of mesenterial filaments; second protomesenteries fertile, shorter than first metamesenteries; third protomesenteries sterile, short but longer than first protomesenteries. Metamesenteries arranged in quartets: $M B m b$. Most $M$ and $m$ metamesenteries reach aboral end, metamesenteries $B$ and $b$ sterile, short, resemble third protomesenteries. Mesenterial filaments of second protomesenteries and $M$ and $m$ metamesenteries with ciliary tract 


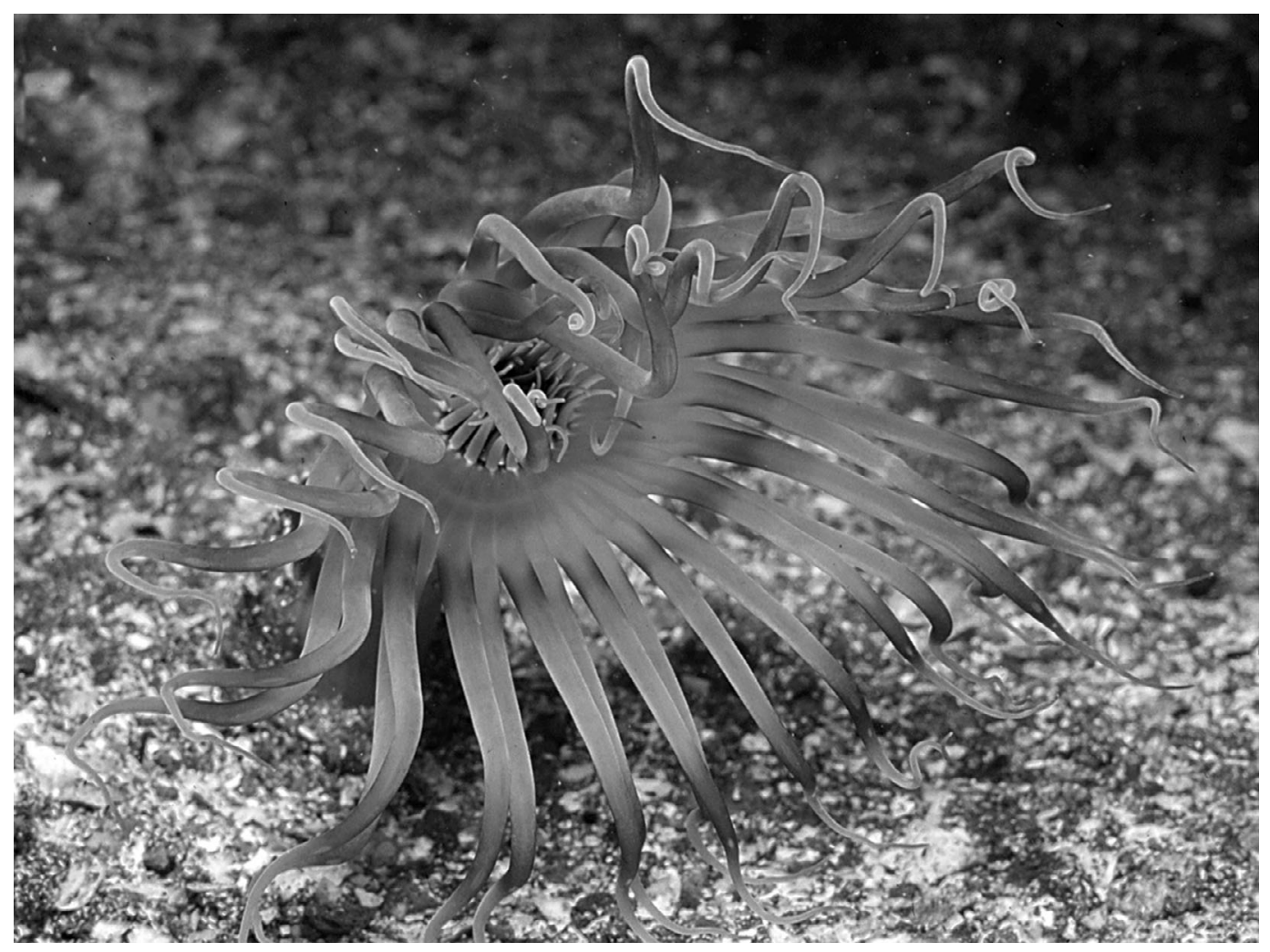

Figure 19. Arachnanthus sp. Oral end of animal in situ. Photograph by Paul Humann.

only; third protomesenteries and $B$ and $b$ metamesenteries each with large region of cnido-glandular tract. Craspedonemes of ciliary tract on all proto- and metamesenteries except directives. Cnidorages (beadlike formations of mesenterial filament containing as many as 10 large basitrichs and numerous small spirocysts) scattered in craspedonemes of ciliary tract, more numerous in bunches of craspedonemes of $m$ and $M$ mesenteries. Cnidom: spirocysts, ptychocysts, basitrichs, microbasic $b$-mastigophores, macrobasic $b$-mastigophores, holotrichs.

RECORDS IN THE GALÁPAGOS ISLANDS: Fernandina (8), Floreana (10, 13), Isabela (26), Rabida (33), Santa Cruz (37), Santiago (44).

DISTRIBUTION OTHER THAN THE GALÁPAGOS IsLANDS: Mexico: Baja California,
Sonora (Carlgren 1951). USA: California (Torrey and Kleeberger 1909).

\section{Suborder Penicillaria \\ Family Arachnactidae}

\section{Aracbnantbus sp.}

Figure 19

Live appearance (Figure 19): Small, with 35-40 slightly curved marginal tentacles arrayed at margin of oral disk in 1-2 pseudocycles. Tips of labial tentacles meet above mouth so whorl of labial tentacles, which are brown or tan, forms a cone. Marginal tentacles grayish with several brown bands on each: bands at tip and base commonly darker than those in middle. Oral disk white or tannish. Tube thin, the consistency of cardboard. 
Commensal phoronid Phoronis australis never reported from tubes of Arachnanthus.

haв IтAт: Among chaetopterid tubes; seen at $13 \mathrm{~m}$.

Detailed ACCOUnT: Actinopharynx rather long, 6-10 mesenteries attached to broad siphonoglyph; hyposulcus about half length of actinopharynx. First protomesenteries (directives) reach aboral part of hyposulcus; second protomesenteries sterile, short, commonly longer than third protomesenteries; each third protomesentery with short ciliary tract and rather long cnidoglandular tract. Metamesenteries arranged in duplets: $M B$. Oldest $M$ metamesenteries with acontioids, several $M$ metamesenteries reach aboral end; metamesenteries $B$ short and with same structure as third protomesenteries. Cnidom: spirocysts, ptychocysts, microbasic $b$-mastigophores, microbasic $p$ mastigophores.

NOTES: This species was first recorded in the Galápagos from underwater photos; its identity was confirmed only after study of preserved material. Currently Aracbnanthus includes five species. Members of family Arachnactidae, which are uniform in appearance and morphology, are distinguished by cnidom and type of the planktonic larvae (Molodtsova 2004). The cnidom of Arachnanthus from Vicente Roca differs from that of $A$. sarsii, $A$. oligopodus, and $A$. australiae.

RECORDS IN THE GALÁPAGOS ISLANDS: Bartolomé (1), Isabela (24), Rabida (33).

KEY TO THE SEA ANEMONES AND CERIANTHIDS OF THE GALÁPAgOS ISLANDS

1A. Animal may be burrowed into sediment but never lives in tube; tentacles cover entire

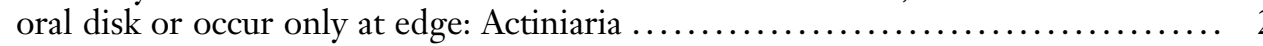

1B. Animal lives within tube, burrowed in sediment; tentacles in two whorls, labial ones around mouth, marginal ones at edge of oral disk: Ceriantharia $\ldots \ldots \ldots \ldots \ldots \ldots 8$

2A. Column entirely covered by small (about $1 \mathrm{~mm}$ diameter), nonadhesive vesicles; acon-

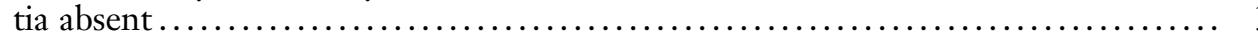

2B. Verrucae (adhesive warts) occur on part or all of column; acrorhagi present; acontia

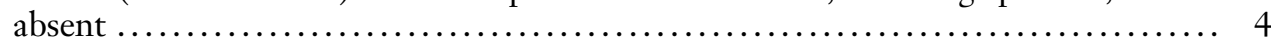

2C. Column smooth; sphincter muscle mesogleal; acontia present or absent........... 5

3A. Tentacles and oral disk with white spots; oral disk undulating ........ Bunodosoma grandis

3B. Tentacles, column, oral disk red; oral disk flat................... Phymactis papillosa

4A. Column dark in color with inconspicuous acrorhagi .............. Anthopleura nigrescens 4B. Column light in color with very prominent acrorhagi............. Anthopleura mariscali

5A. Oral and pedal disks similar diameter to column; with acontia .................. 6

5B. Column commonly broadens basally so pedal disk much broader than oral disk; typically adherent to shell, gorgonian, urchin spine, or some other substratum made by an animal; with or without acontia.................................... 7

6A. Tentacle tip blunt or bulbed; column opaque ................. Telmatactis panamensis

6B. Tentacles relatively long and thin in life, some may be kinked or corkscrewed; column

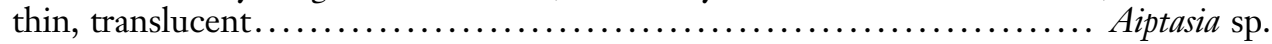

7A. Tentacles relatively short, stout, pointed in life; column thick, opaque, with cinclides; commonly attached to shell occupied by hermit crab; with acontia .. Calliactis "polypus"

7B. Sphincter muscle mesogleal; without acontia ...................... Antiparactis sp.

8A. Marginal tentacles number 160 or more, may be clearly arrayed in inner and outer groups differing in length and color; labial tentacles numerous, hide mouth and even entire oral disk................................ Botruanthus benedeni

8B. Marginal tentacles number 35-40, all similarly colored; labial tentacles form a

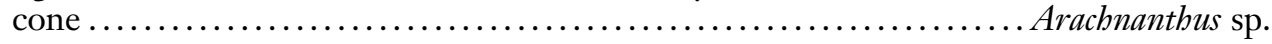




\section{ACKNOWLEDGMENTS}

We thank the crew of the Beagle III, Dale Calder, Fernando Rivera, Lauren E. Garske, and many others for logistical help in the field on one or more of many trips to the Galápagos by C.P.H. and one by D.G.F.; Angel Chiriboga for help with anemone collections and photography; the staff of the Biomarine Laboratory of the Charles Darwin Station for support; Matt James for help with literature; and Adorian Ardelean, Ha-Rim Cha, Andrea Crowther, and Luciana Gusmão for technical assistance such as measuring nematocysts, making histological slides, and taking photomicrographs.

\section{Literature Cited}

Carlgren, O. 1900. Ostafrikanische Actinien. Gesammelt von Herrn Dr. F. Stuhlmann 1888 und 1889. Mitt. Naturhist. Mus. $17: 21-144$.

- 1922 (for 1920). Actiniaria und Zoantharia von Juan Fernandez und der Osterinsel. Pages 145-160 (Chapter 20) in C. Skottsberg, ed. The natural history of Juan Fernandez and Easter Island. Vol. 3. Almqvist and Wiksells Boktryckeri, Uppsala.

1924. Die Larven der Cerianthiaren, Zoantharien und Actiniarien. Wiss. Ergeb. Dtsch. Tiefsee-Exped. 19:339-476.

_. 1938. South African Actiniaria and Zoantharia. K. Sven. Vetenskapsakad. Handl. 17:1-148.

. 1943. East-Asiatic Actiniaria and Corallimorpharia. K. Sven. Vetenskapsakad. Handl. 20:1-43.

. 1949. A survey of the Ptychodactiaria, Corallimorpharia and Actiniaria. K. Sven. Vetenskapsakad. Handl., ser. 4, 1:1121.

- 1950a. Corallimorpharia, Actiniaria and Zoantharia from New South Wales and South Queensland. Ark. Zool. 10:131-146.

. 1950b. Actiniaria and Corallimorpharia. Sci. Rep. Great Barrier Reef Exped. 5:427-457.

. 1951. The actiniarian fauna of the Gulf of California. Proc. U.S. Natl. Mus. 101:415-449.
. 1959. Reports from the Lund University Chile Expedition 1948-1949. Corallimorpharia and Actiniaria with a description of a new genus and species from Peru. Ark. Zool. 71:1-38.

Carter Verdeilhan, D. 1965. Actinias de Montemar, Valparaiso. Rev. Biol. Mar. 12:129-157.

Cutress, C. E. 1977. Corallimorpharia, Actiniaria, Ceriantharia. Pages 130-147 in D. M. Devaney and L. G. Eldredge, eds. Reef and shore fauna of Hawaii. Bishop Museum Press, Honolulu.

Cutress, C. E., and C. A. Arneson. 1987. Sea anemones of Enewetak Atoll. Pages 53-62 (Chapter 6) in D. M. Devaney, E. S. Reese, B. L. Burch, and P. Helfrich, eds. The natural history of Enewetak Atoll. Office of Scientific and Technical Information, U.S. Department of Energy, Washington, D.C.

Daly, M., and D. G. Fautin. 2004. Anthopleura mariscali, a new species of sea anemone (Cnidaria: Anthozoa: Actiniaria) from the Galápagos Islands. Zootaxa 416:1-8.

Dana, J. D. 1846. Zoophytes. U.S. Exploring Expedition during the years 1838, 1839, $1840,1841,1842$ under the command of Charles Wilkes, U.S.N. Vol. 7. Lea and Blanchard, Philadelphia.

. 1859. Synopsis of the report on zoophytes of the U.S. Exploring Expedition around the world, under C. Wilkes, U.S.N. Commander, in the years 18381842. Published by the author, New Haven.

Doumenc, D., C. Chintiroglou, and A. Foubert. 1989. Variabilité du genre Telmatactis Gravier, 1918 (Actiniaria, Acontiaria, Isophelliidae). Bull. Mus. Natl. Hist. Nat., ser. 4, 11 (A): 5-45.

Dunn, D. F. 1974. Redescription of Anthopleura nigrescens (Coelenterata, Actiniaria) from Hawaii. Pac. Sci. 28:377-382.

England, K. W. 1971. Actiniaria from Mururoa Atoll Tuamotu, Polynesia (Hormathiidae; Calliactis polypus Sagartiidae: Verrillactis n. gen. paguri). Cah. Pac. 15:23-39.

- 1987. Actiniaria from the Red Sea and tropical Indo-Pacific. Bull. Br. Mus. Nat. Hist. 53:205-292. 
1992. Actiniaria (Cnidaria: Anthozoa) from Hong Kong with additional data on similar species from Aden, Bahrain and Singapore. Pages 699-705 in B. Morton, ed. The marine flora and fauna of Hong Kong and southern China III. Proceedings of the 4th International Marine Biological Workshop. Hong Kong University Press, Hong Kong.

Fautin, D. G. 1984. More Antarctic and Subantarctic sea anemones (Coelenterata: Corallimorpharia and Actiniaria). Antarct. Res. Ser. 41:1-42.

- 2006. Hexacorallians of the worldsea anemones, corals, and their allies (http://hercules.kgs.ku.edu/hexacoral/ anemone2/index.cfm).

Fautin, D. G., and W. K. Fitt. 1991. A jellyfish-eating sea anemone (Cnidaria: Actiniaria) from Palau: Entacmaea medusivora sp. nov. Hydrobiologia 216/217:453-461.

Forsskål, P. 1775. Descriptiones animalium avium, amphibiorum, piscium, insectorum, vermium; quae in itinere orientali observait. Mölleri, Havniæ.

Haddon, A. C., and A. M. Shackleton. 1893. Description of some new species of Actiniaria from Torres Straits. Sci. Trans. R. Dublin Soc. 8:116-131.

Hand, C. 1975. Class Anthozoa. Pages 85-94 in R. I. Smith and J. T. Carlton, eds. Light's manual: Intertidal invertebrates of the central California coast. University of California Press, Berkeley.

Häussermann, V. 2004. Redescription of Phymactis papillosa (Lesson, 1830) and Phymanthea pluvia (Drayton in Dana, 1846) (Cnidaria: Anthozoa), two common actiniid sea anemones from the south east $\mathrm{Pa}$ cific with a discussion of related genera. Zool. Meded. (Leiden) 78:345-381.

Hertwig, R. 1882. Die Actinien der Challenger Expedition. Gustav Fischer, Jena.

Hickman, C. P., Jr. 1998. A field guide to sea stars and other echinoderms of Galápagos. Sugar Spring Press, Lexington, Virginia.

Hickman, C. P., Jr., and Y. Finet. 1999. A field guide to marine molluscs of Galápagos. Sugar Spring Press, Lexington, Virginia.

Hickman, C. P., Jr., and T. L. Zimmerman.
2000. A field guide to crustaceans of Galápagos. Sugar Spring Press, Lexington, Virginia.

Humason, G. 1979. Animal tissue techniques. 4th ed. Freeman and Company, San Francisco.

James, M. J., ed. 1991. Galápagos marine invertebrates: Taxonomy, biogeography, and evolution in Darwin's Islands. Plenum Press, New York.

Keynes, R., ed. 2000. Charles Darwin's zoology notes and specimen lists from H.M.S. Beagle. Cambridge University Press, Cambridge.

Klunzinger, C. B. 1877. Die Korallthiere des Rothen Meeres. 1: Die Alcyonarien und Malacodermen. Gutmann'schen Buchhandlung, Berlin.

Lesson, R. 1830. Zoophytes. Pages 67-83 in Voyage autour du monde, exécuté par ordre du roi, sur la corvette de sa majesté, La Coquille, pendant les années 1822, 1824, et 1825 . Zoologie. Arthus Bertrand, Paris.

Mariscal, R. N. 1966. The symbiosis between tropical sea anemones and fishes: A review. Pages 157-171 (Chapter 20) in R. I. Bowman, ed. The Galápagos: Proceedings of the Symposia of the Galápagos International Scientific Project. University of California Press, Berkeley.

. 1974. Nematocysts. Pages 129-178 in L. Muscatine and H. M. Lenhoff, eds. Coelenterate biology: Reviews and new perspectives. Academic Press, New York.

McMurrich, J. P. 1893. Report on the Actinix collected by the United States Fish Commission Steamer Albatross during the winter of 1887-1888. Proc. U.S. Natl. Mus. 16:119-216. 1904. The Actiniae of the Plate collection. Zool. Jahrb. 6:215-306.

Molodtsova, T. N. 2004. On the taxonomy and presumable evolutionary pathways of planktonic larvae of Ceriantharia (Anthozoa, Cnidaria). Hydrobiologia 530:261266.

Okey, T. A., S. Banks, A. F. Born, Ro. H. Bustamante, M. Calvopiña, G. J. Edgar, E. Espinoza, J. M. Fariña, L. E. Harske, G. K. Reck, S. Salazar, S. Shepherd, V. Toral-Granda, and P. Wallem. 2004. A 
trophic model of a Galápagos subtidal rocky reef for evaluating fisheries and conservation strategies. Ecol. Modell. 172:383-401.

Okey, T. A., S. A. Shepherd, and P. C. Martínez. 2003. A new record of anemone barrens in the Galápagos. Not. Galápagos 62:17-20.

Parulekar, A. 1968. Sea anemones (Actiniaria) of Bombay. J. Bombay Nat. Hist. Soc. 65:138-147.

Senna, A. 1907. Nuove larve pelagiche di ceriantidi e di zoantidi. Monit. Zool. Ital. 18:96-102.

Song, J.-I. 1992. Systematic study on Anthozoa from the Korea Strait in Korea: Subclasses Zoantharia and Ceriantipatharia. Korean J. Syst. Zool. 8:259-278.

Song, J.-I., and I. S. Lee. 1998. Fauna of anthozoans from adjacent waters of Geojedo Island in Korea. Korean J. Syst. Zool. 14:229-242.

Torrey, H. B., and F. L. Kleeberger. 1909. Contributions from the marine biological laboratory of San Diego XXVII. Three species of Cerianthus from southern California. Univ. Calif. Publ. Zool. 6:115-125.
Uchida, T. 1938. Actiniaria of Mutsu Bay. Sci. Rep. Tohoku Imp. Univ. Fourth Ser. (Biol.) 13:281-317.

Verrill, A. E. 1869a. Review of the polyps of the west coast of America. Trans. Conn. Acad. Arts Sci. 1:377-558.

- $1869 b$. On the geographical distribution of the polyps of the west coast of America. Trans. Conn. Acad. Arts Sci. $1: 558-567$.

- 1899. Descriptions of imperfectly known and new actinians, with critical notes on other species, IV. Am. J. Sci. 7:205-218.

- 1928. Hawaiian shallow water Anthozoa. Bernice P. Bishop Mus. Bull. 49:3-30.

Wirtz, P. 1996. The sea anemone Telmatactis cricoides from Madeira and the Canary Islands: Size frequency, depth distribution and colour polymorphism. Arquipélago 14A:1-5.

Zamponi, M. O. 1977. La anemonofauna de Mar del Plata y localidades vecinas. I. Las anemonas Boloceroidaria y Endomyaria. (Coelentherata: [sic] Actiniaria). Neotropica (La Plata) 23:137-153. 
